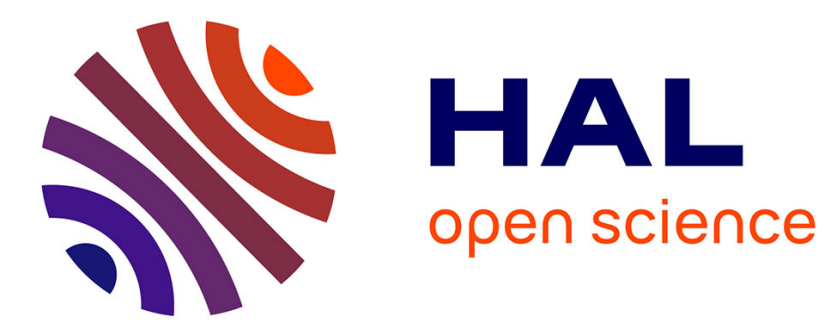

\title{
Mid Holocene vegetation reconstruction from Vanevan peat (south-eastern shore of Lake Sevan, Armenia)
}

Chantal Leroyer, Sébastien Joannin, David Aoustin, Adam A. Ali, Odile Peyron, Vincent Ollivier, Petros Tozalakyan, Arkady Karakhanyan, Fany Jude

\section{- To cite this version:}

Chantal Leroyer, Sébastien Joannin, David Aoustin, Adam A. Ali, Odile Peyron, et al.. Mid Holocene vegetation reconstruction from Vanevan peat (south-eastern shore of Lake Sevan, Armenia). Quaternary International, 2016, 395, pp.5-18. 10.1016/j.quaint.2015.06.008 . hal-01201997

\section{HAL Id: hal-01201997 \\ https://hal-univ-rennes1.archives-ouvertes.fr/hal-01201997}

Submitted on 16 Dec 2015

HAL is a multi-disciplinary open access archive for the deposit and dissemination of scientific research documents, whether they are published or not. The documents may come from teaching and research institutions in France or abroad, or from public or private research centers.
L'archive ouverte pluridisciplinaire HAL, est destinée au dépôt et à la diffusion de documents scientifiques de niveau recherche, publiés ou non, émanant des établissements d'enseignement et de recherche français ou étrangers, des laboratoires publics ou privés. 


\section{Mid Holocene vegetation reconstruction from Vanevan peat (south-eastern shore of Lake Sevan; Armenia)}

Chantal Leroyer ${ }^{1-2 *}$, Sébastien Joannin ${ }^{3-4}$, David Aoustin ${ }^{2}$, Adam A. Ali ${ }^{3}$, Odile Peyron ${ }^{3}$, Vincent Ollivier ${ }^{5}$, Petros Tozalakyan ${ }^{6}$, Arkady Karakhanyan ${ }^{6}$, Fany Jude ${ }^{2}$

${ }^{1}$ Ministère de la Culture, Sous-Direction de l'Archéologie, Paris, France

${ }^{2}$ CNRS-UMR 6566, CReAAH, Université de Rennes 1, MCC, Rennes, France; chantal.leroyer@univ-rennes1.fr; david.aoustin@univ-rennes1.fr; fany.jude@gmail.com

${ }^{3}$ CNRS UMR 5554, ISEM, Université de Montpellier, Montpellier, France; sebastien.joannin@univ-montp2.fr; Ali@univ-montp2.fr; odile.peyron@univmontp2.fr

${ }^{4}$ CNRS UMR 5276, LGL TPE, Université Lyon 1, Villeurbanne, France; ${ }^{5}$ Aix Marseille Université, CNRS, MCC, LAMPEA UMR 7269, 13094, Aix-enProvence, France; ollivier@mmsh.univ-aix.fr ${ }^{6}$ Institute of Geological Sciences, National Academy of Sciences of Armenia, Armenia; georisk@sci.am; tozalakyan@mail.ru

* Corresponding author: Chantal Leroyer ; phone number: +33 (0)2 23235623 ; complete postal address: UMR 6566, Laboratoire ArchéoSciences, Université de Rennes 1, Campus de Beaulieu, bât. 24-25, CS 74205, 35042 Rennes cedex, France, E-mail address: chantal.leroyer@univ-rennes1.fr 


\begin{abstract}
A sediment core has been retrieved from Vanevan peat (south-eastern shore of Lake Sevan, Armenia), which is today disconnected to Lake Sevan thanks to an artificial shallowing of the lake. Based on 5 radiocarbon dates, Vanevan record covers the Mid Holocene (from ca. 7800 to ca. 5100 cal. BP). The Late Holocene is today absent in the peat stratigraphy due to modern peat exploitation by surface milling. This study focuses on a multi-proxies approach including pollen, charcoals and pollen-inferred climate reconstruction.

An open-land, steppic vegetation is recorded up to ca. 7700 cal. BP, followed by a more forested landscape during the Mid Holocene (up to ca. 5700 cal. BP), and ending again with an open-land vegetation (up to the record stop, i.e. 5100 cal. BP). This vegetation dynamics responds to general climate changes documented in the Near East. Whether human activities are documented since ca. 7500 cal. BP (Late Neolithic) in Vanevan, they remain marginal and are probably not affecting Vanevan area. Early Holocene dry climate, which caused the steppic environment to be widely documented through the Near East, is strongly related to low late spring precipitation $\left(P_{\text {May-Jun }}=180 \mathrm{~mm}\right)$. Mid Holocene forested landscape and increasing lake-level seem related to late spring precipitation $(+28 \%)$, which is the main change in estimated climate parameters. This has to be linked with reinforcement of the Westerlies and less active Siberian High, which are inversely involved in the following, dry phase starting at ca. 5700 cal. BP.
\end{abstract}

Keywords: Vegetation, Fire, Climate and Human impacts, Lesser Caucasus, Mid Holocene

Running Head: Mid Holocene palaeoenvironment and palaeoclimate in Armenia

\title{
1. Introduction
}

Located between Black and Caspian Seas, Armenia is the most mountainous country of the Lesser Caucasus. The mean elevation is $1830 \mathrm{~m}$ and $75 \%$ of its area ranges from 1000 to $2500 \mathrm{~m}$. Climate varies from a contrasted continental to mountainous influences. Steppic vegetation is widespread today, and only $8 \%$ of Armenia is covered by exploited and deteriorated forests (it was $18 \%$ back in XVIII century, Sayadyan, 2011), mostly concentrated in North-East and South-East (Chorbajian, 2006). The main challenge is to know if vegetation was always steppic or if a forest phase may have existed during the Holocene. Whether a forested phase is documented during the Mid Holocene in recent studies across Georgia (e.g. Connor and Kvavadze, 2008; Messager et al., 2013), only low resolution pollen analyses (Takhtajyan, 1941; Tumanyan, 1971; Tumajanov and Tumanyan, 1973; Sayadyan et al., 1977; Sayadyan, 1978) suggest that forests once existed in Armenia. Moreover, these studies (in Russian) are not up to today's standards (no dates or few datings on molluscs, up to $40 \%$ unidentified palynomorphs). According to Moreno-Sanchez and Sayadyan (2005), they bring indication to support the idea that broadleaf deciduous forests existed 6000 years ago around the Lake Sevan. If forested landscape was to be confirmed for the Mid Holocene, we then have to decipher the 
start of deforestation and to understand respective role of human impact and/or climate change in the establishment of modern vegetation. It is of great importance in such a mountainous area where environment is harshly treated by strong human pressures and drastic climate conditions.

Whether economy starts relaying on productivity during the $8^{\text {th }}$ millenary BP in Armenia (Chataigner, 2007; Chataigner et al., 2012), it is important to underline that Early-Mid Holocene human impact is not evidenced in palaeoenvironmental data. We must rely on authors (e.g. Turner et al., 2010; Roberts et al., 2011) to state that Early Holocene human activity such as deforestation, slash and burn, over-grazing, seem to be responsible for desertification in the entire Near East. Such an area (i.e. Near East) certainly hides various stories considering longitudinal and latitudinal ranges, varying topography in-between two seas. Armenia, with its central position through Lesser Caucasus, requests for accurate studies to document past environmental changes and their drivers.

Carefully following this aim, we provide a study from Vanevan peat, which is part of Gilli wetland (Jenderedjian, 2005), located in the Sevan Lake watershed. Before Lake Sevan's artificial water-level drop for irrigation and electricity production, which began in 1933 (Gulakyan and Wilkinson, 2002), Gilli wetland was the most important inland waterfowl area in Transcaucasus Region (Jenderedjian, 2005). Therefore, Vanevan area is of major interest as a paleoenvironmental archive from the Lake Sevan's shoreline. In the present study, we rely on hygrophyte composition changes occurring in the wetland and on a wider range to terrestrial vegetation changes in order to characterized both pacing and amplitude of fluctuations. In this way, climate reconstruction inferred from pollen assemblages and charcoal history are expected helping to discuss climate and anthropogenic forcing. Furthermore, past drivers for vegetation changes throughout the Holocene in the Near East are subject to debate between possible changes in influences of the Indian summer monsoon (Djamali et al., 2010) or of the westerlies (Roberts et al., 2011).

\section{Study area}

\subsection{Geological setting}

Vanevan peat $\left(40^{\circ} 11.748 \mathrm{~N} 45^{\circ} 40.099 \mathrm{E}\right.$; alt. $1919 \mathrm{~m}$ a.s.l.) is located south-east of Lake Sevan (1898 m a.s.l.; Fig. 1a), ca. $3.2 \mathrm{~km}$ from the modern shoreline (Fig. 1b). Lake Sevan is the biggest lake in Armenia. It was sizing $1257 \mathrm{~km}^{2}$ and $33.4 \mathrm{~km}^{3}$ in 2006. It is one of the highest mountainous freshwater lakes in the world. Quaternary tectonic forms this lake (Meybeck et al., 1997; Ollivier et al., 2010). Catchment area is about $5000 \mathrm{~km}^{2}$, where 28 rivers feed the lake, while the outflowing Hrazdan River goes through Araxe River to the Caspian Sea. Higher evaporation ( 800 mm.year $^{-1}$ ) than direct precipitation ( $360 \mathrm{~mm}^{\text {year }}{ }^{-1}$ ) causes a negative balance and a slow turnover (50 yrs; Meybeck, 1995). Annual precipitation in the coastal belt is between 350 to $446 \mathrm{~mm}$ and around $800 \mathrm{~mm}$ in the mountain zones (Baghdasaryan, 1958). The use of its water for agriculture and electricity production caused a water lowering $(19 \mathrm{~m})$ and volume lost $(40 \%)$. Since then, eutrophication impacts faunal and floral in and around the lake (Lind and Taslakyan, 2005). The Gilli wetland (1500 ha), from where Vanevan peat belongs, is in alluvial-paludal area influenced by torrential activity. The lowering of the lake for irrigation and electricity, as well as field drainage for agriculture cause the peat drying, and it is currently exploited ( Tumanyan, 1971; Jenderdjian, 2005 ) by milling of surface (Fig. 2). 


\subsection{Present climate and phytogeography}

Today's climate is very contrasted. The Vanevan area is characterized by a mountain climate with mild summers and extremely cold and snowy winters. Dry and cold winters are controlled by Siberian Highs breaks which cause the westerlies to temporarily bring snow over the Lesser Caucasus. In summer, Saoudian Highs can break in the South and bring relatively more humid air. Rains are provided by westerlies and originate from the North Atlantic (Berg, 1950). The meteorological station of Sevan city is the closest station from Vanevan with on line data spanning a long enough time window (http://www.worldweather.org). The study zone is characterised by a low annual temperature $\left(3^{\circ} \mathrm{C}\right.$ on average), with a minimum in January $\left(-8^{\circ} \mathrm{C}\right.$ on average) and a maximum in August $\left(15^{\circ} \mathrm{C}\right.$ on average). Annual precipitation is about $500 \mathrm{~mm}$ with 128 precipitation days in average (Fig. 3). Mountain-valley circulations, due to differential heating, can produce thundershower activity (particularly in late spring, i.e. May-June), while snow retards the rise of air temperature.

According to bioclimatic classification from Zazanashvili et al. (2000), Lake Sevan belongs to the South Uplands type in which Anatolian-Iranian components predominate in the plant communities' floristic composition. It includes two zones: hemi-xeric upper mountain forest and woodland (Quercus macranthera, Pyrus spp., Acer hyrcanum, Juniperus polycarpos in combination with mountain steppes; up to $2300 \mathrm{~m}$ ) and subalpine woodlands (Quercus macranthera in combination with herbaceous vegetation; up to $2800 \mathrm{~m}$ ). The east Caucasus type develops on the northern slope of the mountain chain (Sevan range) north-east of Lake Sevan (Fig. 1b). It includes several zones: Lower Mountain (Fagus orientalis, Carpinus caucasica; up to $1200 \mathrm{~m}$ ), Mesic beech forest (up to $2000 \mathrm{~m}$ ) and Subalpine elfin wood (Quercus macranthera, Pinus kochiana and birch in combination with subalpine herbaceous vegetation; up to $2700 \mathrm{~m}$ ).

More focusing on the lake Sevan surroundings, Bohn et al. (2000) consider here a mountain semi-arid bioclimatic zone. Around Vanevan (Fig. 4), the major vegetation types are Stipa-steppes (M11: mountain type / Pre- and Transcaucasian feather grass steppes). Their composition is both highly varied and species-rich with many endemics (Table 1). To the west of Vanevan, steppe is composed of species from meadow steppes and mountain steppes (M4: Transcaucasian altimontane herbgrass- and meadow steppes). To the east of Vanevan, persists open krummholz forests and open woodlands with endemic trees species, shrubs and grasslands (C46), while alpine grasslands (B58) are present at higher altitudes. North of Lake Sevan, there are Transcaucasian colline-montane juniper open woodlands (Juniperus polycarpos, J. foetidissima), partly in combination with Pistacia muticaopen woodlands (K33).

Considering the Vanevan peatland, today's vegetation is dominated by sedge taxa (such as Cyperaceae, Juncaceae and Phragmites). This wetland dries up during end of summers. 


\section{Methods}

\subsection{Core sampling, lithostratigraphy and chronology}

The coring of the Vanevan sequence was performed in 2011 using a Russian corer. A $164 \mathrm{~cm}$ long core was drilled, recovered in four sections $(A: 0-56 \mathrm{~cm}$; $B: 36-92 \mathrm{~cm}$; C: $72-128 \mathrm{~cm}$; D: $108-164 \mathrm{~cm}$ ) (Fig. 5).

From base to top (based on visual observations), this core contains sandy silt (164 to $150 \mathrm{~cm}$ ), which becomes more argillaceous ca. $156 \mathrm{~cm}$, organo-mineral clays between 150 and $132 \mathrm{~cm}$, organic clays between 132 and $41 \mathrm{~cm}$, and peaty sediment above.

The chronology is based on five Accelerator Mass Spectrometry (AMS) ${ }^{14} \mathrm{C}$ ages (Table 2), performed on organic materials. Unfortunately, no datable macrofossils were found at the base, so the AMS ${ }^{14} \mathrm{C}$ age is determined on bulk sediment samples. Macrofossils were collected from sediment samples sieved with a $100 \mu \mathrm{m}$ mesh screen. Radiocarbon ages were calibrated in yrs cal. BP by the Calib 7.0 software using the calibration curve IntCal13 (Reimer et al., 2009). Dates are expressed as intercepts with $2 \sigma$ ranges. The age-depth model is constructed using an interpolated linear curve (Fig. 5) by the 'Clam' model developed by Blaauw (2010).

\subsection{Pollen analysis}

\subsubsection{Pollen samples}

Thirty-six samples were taken at various intervals $(2$ to $6 \mathrm{~cm})$ across the core. For each sample, $1 \mathrm{~cm}^{3}$ of sediment was processed following the standard methods in palynology using $\mathrm{HF}, \mathrm{HCl}, \mathrm{KOH}$ baths (Fægri and Iversen, 1989) and heavy liquid flotation using zinc chloride. After treatment, the residue was suspended in glycerol, mounted onto microscope slides and counted under a light microscope at a standard magnification of $\times 500$ and $\times 1000$. Two samples were sterile (at 150 and $160 \mathrm{~cm}$ depth).

Pollen flora was identified using photo atlases (Reille, 1992-1998; Beug, 2004) and the reference collection at University of Rennes 1 . The pollen diversity is established to 108 taxa with a mean taxonomic diversity of 41 taxa. Poor in the three lower samples (18 taxa), the diversity increases at 149 and $147 \mathrm{~cm}$ (36 taxa) and especially between 145 and $35 \mathrm{~cm}$ (38-59 taxa). It decreases at the top (24-42 taxa). A total of 26205 spores and pollen were counted with an average sum of 771 per sample (259 to 5698). So, a minimum of 151 to 1192 terrestrial pollen grains, excluding wetland plants (Cyperaceae and aquatics) and spores of pteridophytes, was counted for the poorest and the richest samples, respectively. Palynofacies (algae, microscopic charcoal and organic matter) was observed during the counting. Pollen values were calculated as a percentage of total land pollen excluding Cyperaceae, aquatic plants and fern spores (Fig. 6) but Figure 7 presents a synthetic pollen diagram where Poaceae are also excluded. The pollen diagrams (Figs. 6-7) were produced using Gpalwin software (Goeury, 1997). Local pollen assemblage zones were identified on a visual basis and verified with cluster analyses using Past software (Hammer et al., 2001). The Pollen Indicator of Human Activities (Fig. 7) was calculated with the frequencies of Cerealia-type, Secale, Linum, Centaurea cyanus, Papaver, Rumex acetosa, Convolvulus, Polygonum group and Plantago group (Behre, 1981; Brun, 2011). 


\subsubsection{Pollen-based climate reconstruction}

Quantitative estimates of temperature and precipitation are inferred from Vanevan pollen data with the Modern Analogue Technique 'MAT' (Fig. 7) which has already been tested in Armenia from the Zarishat pollen assemblages (Joannin et al., 2014). In the MAT (Guiot, 1990), the similarity between each fossil sample and modern pollen assemblage is evaluated by a chord distance. Estimates of past climatic parameters are calculated by taking a weighted average of the values for all selected best modern analogues (here 8 ). To reduce uncertainties in the climate reconstruction, which often occur with steppic pollen assemblages, we have applied to the analogue selection a constraint by biomes. A biome is assigned to each modern and fossil pollen sample following a procedure based on a plant functional type-pollen data attribution Peyron et al. (1998). Winter and late spring precipitation $\left(P_{\text {win }}, \mathrm{P}_{\text {May-Jun; }}\right.$ Fig. 7$)$ are the hydrological parameters that are assumed to have the strongest relationship with pollen data in Armenia (Joannin et al., 2014). In southern Georgia also, statistical analysis showed that rainfall was the parameter most strongly correlated with pollen composition (Connor and Kvavadze, 2008). The temperature of the coldest month (MTCO) is reconstructed for comparison with previous studies because this variable imposes a limit on the growth of plants. To reduce the potential effect of spatial autocorrelation (Telford and Birks, 2005), we have used the same modern pollen dataset than for the Zarishat reconstruction, which include the update of the European modern pollen dataset by adding 45 surface samples from southern Georgia (Connor et al., 2004; Connor and Kvavadze, 2008). The updated dataset used here contains 3058 surface samples.

\subsection{Macroscopic charcoal analysis}

Macroscopic charcoal samples of $1 \mathrm{~cm}^{3}$ were taken contiguously. Samples were soaked in a $3 \%\left(\mathrm{NaPO}_{3}\right)_{6}$ solution for a minimum of 2 days before wet sieving through a $160-\mu \mathrm{m}$ screen. The remaining particles were bleached in a $10 \% \mathrm{NaOCl}$ solution to aid in distinguishing charcoal from dark organic matter. The sieving method is assumed to represent local-scale fires, i.e. $1 \mathrm{~km}$ from the fen (e.g. Carcaillet et al., 2001; Higuera et al., 2007). Identification, counting and area measurements of charcoal particles were undertaken using a 20x stereoscope coupled with a digital camera and image-analysis software (Regent Instruments Canada Inc.).

\section{Results and interpretation}

\subsection{Age model}

One ${ }^{14} \mathrm{C}$ age (D-42.5 at depth $150.5 \mathrm{~cm}$ ) was excluded from the age-depth model (Fig. 5), having both low organic content and large error margin (9860 \pm 380 ; Table 2 ). So the age-depth model is extrapolated to the base of the core. Considering the surprising age obtained at $24.5 \mathrm{~cm}(4745 \pm 35)$ and keeping in mind the possible effect of present-day peat exploitation by milling the surface observed at 300-400 m away from the coring site (Fig. 2), we get an extra ${ }^{14} \mathrm{C}$ date at $10.5 \mathrm{~cm}$ depth. Accuracy of this age $(4580 \pm 30)$ claims for no reversion of the sediment surface. This suggests sediment removal over the coring area. We decided to stop the pollen count at $5 \mathrm{~cm}$ depth. Tumanyan (1971) already mentioned such peat extraction in 
Gilli area. This also caused removal of the uppermost part of the peat at his coring location.

Sedimentation rate varies from base to top. It is first $0.5 \mathrm{~mm} . \mathrm{yr}^{-1}$ from 160 to $145 \mathrm{~cm}$, then $0.6 \mathrm{~mm} . \mathrm{yr}^{-1}$ up to $100.5 \mathrm{~cm}$. Between 100.5 and $50.5 \mathrm{~cm}$, accumulation rate increases to $0.98 \mathrm{~mm} . \mathrm{yr}^{-1}$. Interval 50.5 to $24.5 \mathrm{~cm}$ includes a major lithological change; peat accumulation causing the sedimentation rate to decrease to $0.28 \mathrm{~mm}$.yr ${ }^{-1}$. For the uppermost section, the rate increases $\left(0.63 \mathrm{~mm} . \mathrm{yr}^{-1}\right)$.

Based on this age-model, the Vanevan record covers about 3000 years from ca. 7800 to ca. 5100 cal. BP. The early Holocene is absent due to sterility of basal pollen samples and late Holocene is no more available in the coring area. The average temporal resolution for the pollen analysis is estimated to $79 \mathrm{yrs}$ between samples (min to max: 33 to 176 yrs between samples).

\subsection{Pollen analysis}

\subsubsection{Pollen sequence}

Five main LPAZs (Local Pollen Assemblage Zones) have been distinguished in the Vanevan pollen record (Figs. 6-7).

LPAZ Van 1 (depth: $155-151 \mathrm{~cm}$ ) is recorded in the sandy silt, spanning the period from 7800 to $7740 \mathrm{cal}$. BP. It is dominated by taxa from open ground (Cichorioideae, Chenopodiaceae, Poaceae and Asteraceae) and steppic taxa such as Artemisia. Hygrophilous vegetation is scarse and only includes Cyperaceae. The Tree component is rare, essentially composed of Ephedra distachya t., Juniperus then Pinus. Low but continuous amounts of Quercus and UImus are recorded. LPAZ Van 1 ends with slight increases of Cyperaceae and Quercus, while Betula appeared. LPAZ Van 2 (depth: $149-135 \mathrm{~cm}$ ) is recorded in the organo-mineral clay, spanning the period from 7700 to $7470 \mathrm{cal}$. BP. This zone records a general tree expansion, where all tree taxa from LPAZ Van 1 increase (except Pinus and Ephedra distachya t.) added by appearance of numerous tree taxa such as Betula, Carpinus, Fagus, Ostrya t., Tilia, Fraxinus, Acer, Hippophae, Alnus and Salix. Quercus is the most dominant tree taxa, followed by Juniperus, which attains its maximum in this zone. Poaceae and Artemisia increase while Cichorioideae, Chenopodiaceae and Asteraceae strongly decrease. Similarly to tree taxa, herbs also become richer by adding heliophilous taxa (Brassicaceae, Rumex, Polygonum, Plantago) or hygrophytes (Sparganium, Potamogeton, Typha, Myriophyllum, Ranunculaceae, Liliaceae, Rosaceae, Filipendula). First occurrence of Cerealia-type is recorded. Subdivision into two subzones (Van 2a, depth: 149 - $147 \mathrm{~cm}$ and Van 2b, depth: 145 $-135 \mathrm{~cm}$ ) highlights the lowering in amounts of Cichorioideae, Chenopodiaceae and Thalictrum. Additionally, LPAZ Van 2 shows continuous appearance of algal taxa such as Botryococcus and Pediastrum.

LPAZ Van 3 (depth: $131-100 \mathrm{~cm}$ ) is recorded in the organic clays, spanning the period from 7400 to $6890 \mathrm{cal}$. BP. and divided into three subzones (Van 3a, depth: $131-125 \mathrm{~cm}$; Van 3b, depth: $121-110 \mathrm{~cm}$ and Van 3c, depth: $105-100 \mathrm{~cm})$. On the whole, Van 3 records a decreasing in Juniperus, and a maximum development of Hippophae. Quercus is still the dominant tree taxa, along with Ulmus and Carpinus. Noteworthy is the presence of Phyllirea-Olea and Pistacia pollen grains. Considering herbs, increases of Thalictrum and hygrophytes are recorded while cereals (Cerealiatype and Secale) are regularly seen in the pollen assemblages. Van 3a mainly shows the Quercus increase, Van 3b its decrease and Van 3c the Juniperus and Hippophae 
decreases while Carpinus increase. Van $3 \mathrm{~b}$ also characterizes higher amounts of Cyperaceae and aquatic taxa, the last becoming more diversified before declining in Van 3c. Algal taxa such Botryococcus and Pediastrum are continuously present during Van 3.

LPAZ Van 4 (depth: $95-35 \mathrm{~cm}$ ) is recorded in the organic clays and at the base of peat, spanning the period from 6840 to $5860 \mathrm{cal}$. BP. This period is divided into three subzones (Van 4a, depth: $95-85 \mathrm{~cm}$; Van 4b, depth: $80-45 \mathrm{~cm}$ and Van 4c, depth: $40-35 \mathrm{~cm})$. In overall, this period is characterized by an increasing of Chenopodiaceae, Cichorioideae, Asteraceae and Cyperaceae along with a decreasing of Poaceae, Sparganium and hygrophytes taxa. .More precisely, Van $4 a$ mainly shows a slight increase in Quercus and Betula. Van 4b shows the increase in Artemisia. Van 4c records less diversified tree taxa, but a slight increase in Carpinus pollen amount. This subzone also records strong increase in Sparganium together with weaker increases of Typha and other aquatic taxa (Myriophyllum spicatum, M. verticillatum, Polygonum amphibium, Lemna, Utricularia). Van 4 shows Pediastrum algae being discontinuously present.

LPAZ Van 5 (depth: $30-5 \mathrm{~cm}$ ) is recorded in the peaty sediment, spanning the period from 5680 to $5190 \mathrm{cal}$. BP and divided into three subzones (Van 5a, depth: 30 $-25 \mathrm{~cm}$; Van 5b, depth: $20-10 \mathrm{~cm}$ and Van $5 \mathrm{c}$, depth: $5 \mathrm{~cm}$ ). On the whole, this zone is marked by a decrease in tree taxa both in quantity and in percentage abundance. A strong increase in Poaceae and ferns is recorded while previously described aquatics decrease. Cyperaceae remains rather abundant, although its percentage is strongly varying. As the Poaceae pollen grain may indistinctively being product by grass or Phragmites, that is to say by less or more local vegetation, pollen diagram can be observed again after excluding Poaceae (Fig. 7). In this case, Quercus remains stable, while Juniperus and Carpinus increase as well as Artemisia and Chenopodiaceae. In Van $5 a$, pollen indicators of human activities decrease. Van $5 \mathrm{~b}$ shows slight increases of Pinus and decreases of Juniperus and Carpinus. Aquatics almost disappear and ferns develop. Van $5 \mathrm{c}$ shows a decrease in Poaceae amount and the fern maximum (together with sporangium being observed in this sample). Van 5 shows algal taxa disappearance.

\subsubsection{Pollen-based climate reconstruction}

For all samples, 8 modern analogues have been selected for the climate reconstruction. These modern analogues are mainly located in southern Georgia and in Armenia cold steppes for the Early/Mid Holocene climate reconstruction (ca. 7800 to 5800 cal. BP), and they are located in Georgia, Armenia, Soviet Union and Tibetan for the late Holocene (ca. 5700 to 5200 cal. BP) The climate reconstruction appears robust for all the sequence: the adopted threshold is 65.59, and the Chord distance which measures the quality of the modern analogues is low, except for two samples corresponding to $7800 \mathrm{cal}$. BP.

During the 2700-year-long record, the mountain climate of Sevan seems to be well reconstructed and the values reconstructed for the coldest month are $\sim 2{ }^{\circ} \mathrm{C}$ (for the Mid-Holocene to 5750 cal. BP) higher than today's values (Fig. 7). The first part of the record (from ca. 7700 to 5750 cal. BP) is climatically stable (even if a decreasing temperature trend can be evidenced) and shows higher values than the second part (from ca. 5750 cal. BP onwards). It is noteworthy that the shift, which took place at ca. 5700 cal. BP resulted in a considerable change of the climate conditions, both in terms of precipitation $\left(\Delta \mathrm{P}_{\text {May-Jun }}=-120 \mathrm{~mm}\right)$ and temperature $\left(\Delta_{\text {MTсO }}=-4{ }^{\circ} \mathrm{C}\right)$. When 
considering the seasonal parameters for precipitation, it appears that the winter precipitation is stable and plays a minor role. In contrast, an increase is evidenced in late spring precipitation at the beginning of the Mid Holocene (ca. $7700 \mathrm{cal}$. BP); then precipitation strongly decreases at 5700 cal. BP.

\subsection{Macroscopic charcoal analysis}

Charcoal particles are found down to $128 \mathrm{~cm}$ in the core. As there are no charcoals at the base of the sequence, the fire activity provides a 2200-year-long record (Figs. 7-8). Unfortunately variations in CHAR (Charcoal Accumulation Rate) with unpredictable background component prevent to reconstruct fire episodes.

Figure 8 also includes length-to-width ratio against time. Ratio values $<0.5$ indicate that fires mostly burned sedge and grassland vegetation (Aleman et al., 2013).

Therefore, two phases are shown by concentration of charcoal and by length-to-width ratio. First, from base (i.e. $128 \mathrm{~cm}$ ) to ca. $5750 \mathrm{cal}$. BP $(40 \mathrm{~cm})$, no fire activity is detected and length-to-width ratio values are dispersed. Second, abundant charcoals from ca. 5750 to 5400 cal. BP show four burning peak maxima and a plateau in ratio values from $40 \mathrm{~cm}$ onward.

\section{Discussion}

Today located on the verge of Lake Sevan (1898 m a.s.I.), Vanevan sequence (1919 $\mathrm{m}$ a.s.I.) is retrieved from the littoral zone, which is of estuarine type. Indeed, before the artificial lowering (ca. $20 \mathrm{~m}$ ), which recently occurred, this marsh was connected to Lake Sevan (Sayadyan, 2002; Jenderedjian, 2005). Considering its past, Vanevan area may have experienced various situations from being part of the lake (but never under deep water) to a suspended peat relatively independent. These have implication on the pollen types, which are trapped in the sediment. Whether pollen from ligneous taxa are usually favoured in the pollen record compared to herbaceous taxa (e.g. Sugita, 1993; Sugita et al., 1999), highly diversified hygrophilous taxa claim for a more local component in pollen origins, although long-distance transported tree pollen certainly exist.

\subsection{A steppic environment until 7700 cal. BP}

The lowermost part of the sequence is dominated by detritic sedimentation (sandy silt) and by herbs: Cichorioideae, Poaceae and Chenopodiaceae. High amounts of Cichorioideae can be considered as taphonomically biased as this pollen grain is less easily corroded than other grains (e.g. Bottema, 1975; Hall, 1981; Havinga, 1984; Lebreton et al, 2010). According to Havinga (1984), dominance of Cichorioideae is associated with low taxa diversity and inconsistencies in the pollen assemblage. At Vanevan, taxa diversity is indeed low, but pollen assemblage consistency appears robust as several steppic taxa are observed (such as Artemisia, Chenopodiaceae, Caryophyllaceae, Carduaceae, Rubiaceae ...), together with trees such as Ephedra distachya $t$., and $E$. fragilis t. Contemporaneously, similar pollen assemblages existed at Zarishat fen (Joannin et al., 2014) and Lake Paravani (Messager et al., 2013). Therefore, Cichorioideae are widespread before ca. $7700 \mathrm{cal}$. BP, although their values are probably reinforced by corrosion. 
These samples show open vegetation, dominated by steppe meadows (Compositeae, Chenopodiaceae, Poaceae and Artemisia). Trees are probably absent from direct surroundings as attested by rare tree pollen grains and rather low prevalence of Pinus and Juniperus, which are long-distance transported pollen grains (Connor et al., 2004). Vanevan area (i.e. $1919 \mathrm{~m}$ a.s.l.) is not occupied by aquatic vegetation as only few Cyperaceae grow. Sandy-silt sedimentation, which refrains spreading of hygrophytes, can indicate velocity of moving waters or more likely ephemeral fens on alluvial deposits (as observed in the higher elevated Zarishat fen, Joannin et al. 2014). In the first case, relatively deep water coincides with wet conditions pointed out by Roberts et al. $(2001 ; 2011)$ for the Early Holocene. This conclusion is based on paleohydrological records, cave carbonates and marine cores, and extends over both East Mediterranean and Middle East (from Greece to Iran). However, Sayadyan $(1978,2009)$ and Sayadyan and Aleshinskaya (1991) reported a progressive increasing of water level based on mollusc assemblages from Norashen site (northwest of Sevan Lake). This increase starts after a low-stand (terrace located at 1861.5-1865.5 $\mathrm{m}$ a.s.I.) during the estimated time interval 10000 to 8000 cal. BP. It attains a high-stand (estimated between 8000 to 6000 cal. BP; (terrace located at 1919.4-1923.4 m a.s.I.) during which water level starts to decrease at around ca. 7000 cal. BP (according to online NOAA data). If these studies are not up to today's standards, they bring useful indication to corroborate the possibility of a very high water level before 7700 cal. BP.

Open-land vegetation observed south east of Sevan Lake matches similar pollen assemblages from Lesser Caucasus and Anatolian area: in Armenia (Shamb-2 travertine, Ollivier et al., 2011; Zarishat, Joannin et al., 2014), in Georgia (Paravani, Messager et al., 2013), in Turkey (Van Lake, Van Zeist et Woldring, 1978, Wick et al, 2003; Eski Acigol, Roberts et al., 2001) and in Iran (Lake Urmia, Bottema, 1986, Djamali et al., 2010; Zeribar, Van Zeist and Bottema, 1977; Mirabad, Stevens et al., 2006). Similar open-land vegetation are also confirmed in pollen records in a synthesis from the Balkan peninsula to Southern Siberia (Wright et al., 2003), in lowland Bulgaria (Filipova-Marinova et al., 2013; Connor et al., 2013), in the Black Sea marine record 22GC3 (Shumilovskikh et al., 2012), in Caspian Sea (e.g. Leroy et al., 2013, 2014), in Central Asia at lake Sonkul (Mathis et al., 2014) and in the Eurasian synthesis including different biotic (e.g. pollen and diatoms) and abiotic proxies (e.g. $\delta^{18} \mathrm{O}$ and lake-level) developed by Chen et al. (2008).

Steppic meadows indicate dry climate conditions, corroborated by Ephedra pollen occurrences (Wick et al., 2003). Such dry climate during Early Holocene (ca. 120008000 cal. BP) is observed by all previously cited authors; Chen et al. (2008) extended it to all Arid Central Asia (ACA). Several authors (Van Zeist et Bottema, 1977; Bottema, 1986; Wick et al., 2003; Connor and Kvavadze, 2008; Djamali et al., 2008; Litt et al., 2009; Joannin et al., 2014) agree to link this arid climate to low spring precipitation, which maintains up to ca. 8000-7500 cal. BP. Vanevan record confirms this general climate scenario as pollen-based climate reconstruction records low May-June precipitation $\left(\mathrm{P}_{\text {May-Jun }}=180 \mathrm{~mm}\right)$ compare to annual precipitation $\left(\mathrm{P}_{\mathrm{ann}}=635\right.$ $\mathrm{mm}$ ) (Figs. 7 and 8). Causes of such conditions are still under debate. According to Djamali et al. (2010), it is due to a typical Mediterranean continental climate (mainly winter-dominated precipitation) in which spring precipitation is reduced or eliminated by northward shifts of the inter-tropical convergence zone (ITCZ) and subtropical anticyclonic belt that prevented the eastward penetration of the North Atlantic and Black Sea lows., While Chen et al. (2008) relate arid conditions to water gas deficit due to North Atlantic low sea surface temperature (SST) and low temperature of high 
altitude air masses. Additionally, Wick et al. (2003) and Joannin et al. (2014) hypothesised that strong Siberian Highs most probably blocked westerly winds (and precipitation) and caused dry late springs. More data are needed to correctly address these hypotheses, as the Vanevan record only starts at the end of this phase.

\subsection{A forested landscape between $7700-5700$ cal. BP}

Since 7700 cal. BP, the deciduous trees and Poaceae increase rapidly along with a decrease of Cichorioideae and Chenopodiaceae. Sustainability of the sedimentary deposition relies on a brief transitory period (from ca. 7700 to 7630 cal. BP) including Chenopodiaceae and steady increasing Quercus amounts in spite of the usually observed transitory step of light-demanding pioneer taxa (e.g. Leroyer et al., 2011; Joannin et al., 2013). Moreover, similar and contemporaneous rapid environmental changes have been documented in other records in the Near East (Fig.8; e.g. Stevens et al., 2006; Shumilovskikh et al., 2012; Messager et al., 2013; Joannin et al., 2014).

During the following two thousand years (from ca. 7700 to ca. 5700 cal. BP), the amount of tree pollen grains vary between 30 and $40 \%$. Pollen assemblages are dominated by Quercus associated with numerous deciduous trees (Ulmus, Betula, Tilia, Fraxinus, Fagus, Carpinus), while Pinus percentage is low (<2\%). Increasing of ligneous taxa might suggest woodland development in the surroundings of Lake Sevan. Studies focussing on modern samples from Georgia (Connor et al., 2004) show that Pinus rate dominates in samples from subalpine zone while Quercus is dominant only where oak is well established (i.e. wood-land). In the lesser far pollen records (Paravani and Zarishat), indicated to be more forested than today (2073 m a.s.l.; Messager et al., 2013) and higher than the tree-line (2116 $\mathrm{m}$ a.s.l.; Joannin et al., 2014), respectively. There, Pinus is better recorded than at Vanevan. The synthesis developed by Connor and Kvavadze (2008) for Georgia shows that today's subalpine zones were more forested by deciduous trees during the Mid Holocene. Therefore, we can easily interpret tree pollen recorded at Vanevan as significantly showing more forested surroundings than today. Compare to works done in Georgia (transects from lowlands to montane), we cannot assuredly be convince of longdistance transported pollen grains from lower altitudinal vegetation zones due to different topographical characteristics of the Vanevan surroundings (i.e. circled by montane ranges West, South, East and North). This highlights that tree pollen grains recorded are mainly growing in direct surroundings.

At Vanevan, dominance of Quercus can be supported by Quercus macranthera, which is well established today in Armenia (Bohn et al., 2000). Until 7470 cal. BP, Juniperus is well recorded. This taxon is today part of the hemi-xeric upper montane forest (Zazanashvili et al., 2000) but stands of Juniperus polycarpos and $\mathrm{J}$.

foetidissima occurred on the northern border of Lake Sevan (Fig. 4; Bohn et al., 2000). Between 7300 and 6890 cal. BP, Phyllirea-Olea followed by Pistacia are recorded first discontinuously and then continuously. These taxa are underrepresented in pollen assemblages (van Zeist and Woldring, 1977; Bottema, 1986), therefore they may have been part of the forest ecosystem. Today, stands of Pistacia mutica are observed north of Lake Sevan associated with junipers (Bohn et al., 2000). Since ca. 7600 cal. BP, Carpinus $($ C. betulus $=$ Carpinus and C. orientalis $=$ Ostrya type; Beug, 2004) and Fagus are recorded. Carpinus increased after ca. 6900 cal. BP but Fagus and Ostrya (C. orientalis type) disappeared between ca. 6700 and 
6400 cal. BP. They are today localised on northern slopes of the northward montane range (Fig. 4; Bohn et al., 2000). Inconstant occurrences of Abies and Picea are recorded around ca. 6500 cal. BP and 6380 cal. BP, respectively. Picea is contemporaneously recorded in Zarishat (Joannin et al., 2014) but appears earlier in Paravani (Messager et al., 2013) as well as Abies, which develops since 8200 cal. BP. From 6600 cal. BP, occurs an opening associated with reinforcement of Pinus, decreases or disappearances of several ligneous taxa, and an increasing of steppic meadows as well as a change in steppe composition (i.e. previously Poaceae and Artemisia, then Chenopodiaceae and Cichorioideae).

From ca. 7700 to ca. 5700 cal. BP, Vanevan area is progressively colonised by aquatic vegetation reaching an optimum, both in abundance and diversity between ca. 7240 and ca. 7060 cal. BP. Establishment of three species of Myriophyllum certainly indicate relatively deep and well-oxygenated water (1-6 meters; Fare et al., 2001). This is confirmed by the recording of fresh water algae such as Botryococcus and Pediastrum. Shallower water is inhabited by amphibious plants such as Cyperaceae and Filipendula (Haslam et al., 1982). From ca. 6840 cal. BP onwards, Myriophyllum become rarer. In place develop Sparganium, Potamogeton and Cyperaceae. This change, which signs a shallowing of water becoming mesotrophic (Cook, 1990), ends with the development of Sparganium and Typha from ca. 6030 to ca. 5700 cal. BP. Shallowing, which hereafter continues however with fresh water algae still developing, may therefore be produced by two factors: organic matter accumulation through plant growth or lake level decreasing. Going back to the work of Sayadian and colleagues on the Norashen Site and terraces of Sevan lake, they report a regressive phase of Lake Sevan from ca. 7000 to ca. 6200 cal. BP (still containing mollusc shells) and eventually reaching its maximum low-stand between 6200 and 4000 cal. BP. At this time, the lake was at lower altitude (terrace located at 1894.5-1896.5 m a.s.I.; Sayadyan, 2009) than Norashen site, which contains a cultural horizon of remnants of ancient building (rich in artefacts: ceramics, stone and animal bone tools; Sayadyan, 1978) (third millennium BC according to Sayadyan et al., 1977).

From ca. 7670 cal. BP onward, Cerealia-type (as described by Beug, 2004 and Tweedle et al., 2005) is sporadically recorded at Vanevan followed by two periods of continuous occurrences (7060 to 6890 cal. BP, 6440 to 5860 cal. BP). Secale-type is also observed. In European pollen analysis, they are associated with ruderal plants and suggest agro-pastoral activities (Behre, 1981). According to Badalyan et al. (2010), plant domestication ages back to the $8^{\text {th }}$ millennium BP. An obsidian source (Khorapor), probably used since the Neolithic, is located not far from Vanevan (ca. $20 \mathrm{~km}$ southward; Chataigner and Gratuze, 2014). However, major incertitude remains when talking about cereals in Caucasia, as there are wild and diverse cereals, some of them being possibly used for alimentary purpose but not cultivated during the Neolithic (Connor et al., 2004). Furthermore, several Poaceae in the Middle East provide pollen grains of Ceralia-type (van Zeist et al., 1975; van Zeist and Wolring, 1978). Concerning Secale-type pollen grains, Frederiksen and Petersen (1998) have documented wild rye (S. cereal ssp. ancestrale) and herbs S. sylvestre and $S$. vavilovii from, which pollen is not distinguishable from the cultivated species $S$. cereale. Ruderal herbs can also be part of steppic vegetation and therefore not being human induced (Behre, 1990; Wick et al., 2003). Therefore, without other indication such as forest openings or pastoral activities indicated by non-pollen palynomorphs (van Geel and Aptroot, 2006), it is but too exaggerated to express that 
farmers were living on the lakeshores, although this hypothesis is plausible but not yet documented.

Pollen-based climate reconstruction shows after ca. 7700 cal. BP an increase in annual precipitation (not shown, $\Delta \mathrm{P}_{\text {ann }}=85 \mathrm{~mm},+13 \%$ ) mainly due to spring precipitation $\left(\Delta \mathrm{P}_{\text {May-Jun }}=50 \mathrm{~mm},+28 \%\right)$ (Fig. 7). Mean temperature of the coldest month (MTCO) stabilises at ca. $-7.5^{\circ} \mathrm{C}$. Increasing precipitation, particularly in spring is therefore documented to be the main change at the onset of the Mid Holocene. Such change is also recognised by a rapid afforestation (Fig. 8) in the Lesser Caucasus (Connor and Kvavadze, 2008; Messager et al., 2013; Joannin et al., 2014), in Anatolian Plateau (Wick et al., 2003) and in Northern Iran (Stevens et al., 2001 ; 2006) where climate conditions are more humid than today's ones. According to Chen et al. (2008), a more humid Mid Holocene period extends eastward across Asia until China. In turn, sediments from Vanevan area contain more organic matter, suggesting a stronger surface biological activity and lower runoff in the more forested catchment. Similar processes are reported in Esci Acikol (Roberts et al., 2001), Lake Van (Wick et al., 2003) and Lake Paravani (Messager et al., 2013). Zarishat catchment, though smaller, also records lower erosion probably thanks to stabilised slopes by meadows (Joannin et al., 2014). In the studied area (i.e. Lesser Caucasus), Mid Holocene climatic optimum relies primarily on more effective precipitation brought during spring (May to June) by the Westerlies. This period marks the installation of present day climate over the East Anatolia and North Iran with rainy late spring and cool/warm and dry summer. Today's precipitation in Eastern Black Sea (i.e. Georgia, North Armenia) results from depression preferentially following the track over Black Sea. The Near East precipitation regime change coincides with the opening of the Black Sea corridor, which led to the conversion of lacustrine waters to marine waters in the Black Sea at around 83008000 cal. BP (e.g. Filipova-Marinova et al., 2013) and certainly change evaporation rates over Black Sea. Therefore, it has been highly debated that the Black Sea corridor opening is the cause of this climate shift (Shumilovskikh et al., 2012). Without disregarding effects of such a change into the Black Sea, geographical sizing of the climate change is more likely to be related to a change in the climate mechanisms equilibrium at a larger geographical scale; reinforcement of the Westerlies and less active Siberian Highs.

\subsection{Palaeoecological changes from 5700 to 5100 cal. BP}

Poaceae increasing amount and diminishing values of trees in the uppermost part of Vanevan record can be explained in different ways. One explanation can be the human impact by deforestation. However, pollen indicators of human activity disappeared. In the case of pastoral activities without cereal cultivation, It is possible to note a decrease in arboreal pollen but no increase of anthropogenic pollen indicators. Without coprophilous fungal spores record (van Geel and Aptroot, 2006), this hypothesis cannot be documented; we suppose that Poaceae increase is not a consequence of forest opening. Moreover, archeological remains around Sevan Lake are dating back to the Early Bronze Age (Sayadyan, 1978).

A second explanation is to interpret Poaceae pollen grains as belonging to Phragmites and therefore, this taxon is participating to the peat-land dynamic which started during the Mid-Holocene (ca. 7000 cal. BP). After Sparganium development, which provides organic matter to accumulate, helophytes develop in turn (Carex and Phragmites or Molinia then fern). A close origin for pollen is corroborated by findings 
of pollinia and fern sporangies. In this hypothesis, organic matter accumulation is the only driver of the local hygrophilous vegetation change and therefore, by the odds of relative percentage, causes artificial decrease of the surrounding vegetation signal. Poaceae must be excluded from the pollen sum when calculating other pollen percentage (Fig. 7). In this case, woodlands are still dominated by Quercus (i.e. hemi-xeric upper mountain forest and woodland according to Zazanashvili et al., 2000) with more developed Carpinus and Juniperus stands. If Juniperus may come from the Lake surroundings as today, Carpinus development may sign a transport from the northern slopes of the Sevan range $(<10 \mathrm{~km})$. From ca. $5400 \mathrm{cal}$. BP, only Quercus is well developed while steppes widespread. However, in this second explanation, one must question how hygrophilous vegetation succession can accommodate one to several meters of water this fast (from ca. 6000 to ca. 5700 cal. BP; Fig. 7) by producing less than $10 \mathrm{~cm}$ of sediment. Another way to explain a hygrophilous vegetation succession is to consider a lake shallowing. A water-level decrease of Sevan Lake is discussed by Sayadyan $(1978 ; 2009)$ in Norashen site between ca. 6200 and 4000 cal. BP. This coincides, in several paleoenvironmental records in the Near East (synthesized in Figure 8), with forest openings (Zeribar, Paravani), declining precipitation (Mirabad, Ispani II) and increase in fire frequency (Zarishat) and activity (Vanevan).

Therefore, a third explanation for the Poaceae increasing amount is that this pollen grain is provided both by local vegetation (i.e. Phragmites) and by open-land grassland that are indubitably to develop at a time of drying condition particularly well evidenced by the Lake Sevan regressive phase (Sayadyan, 1978; 2009). In this hypothesis, dry climate is the driver of the lake low-stand, which is itself the dominant driver of the rapid peat-land vegetation succession. This scenario would involve an intermediate forest regression compare to presented curves in Figures 7 and 8 . In this interval of high Poaceae percentage, macrocharcoals show an increasing fire activity. As particles sizing become very regular (Fig. 8), fire seems to affect only one source of bio-fuel, which is likely to be local and affecting Cyperaceae and

Phragmites (i.e. a part of Poaceae). This has also been observed in Zarishat wetland (Joannin et al., 2014) and link to drying climate conditions rather than human induced fire. At Vanevan, disappearance of human activity pollen indicators claims for no human impact on this fire activity.

At ca. 5200 cal. BP, increase of human activity pollen indicators and Centaurea cyanus, a plant related to cereal culture in central Europe, may show evidence for human presence and impact over Lake Sevan surroundings. This human being settlement is evidenced by Early Bronze Age archeological findings (Sayadyan, 1978). Nevertheless, only few pollen grains of Centaurea cyanus are a poor indicator of human activity. Moreover anthropogenic pollen indicators do not exceed the values during the Mid-Holocene. Therefore they cannot be interpreted only as indicators of human activities. At that time, human seems not to depend upon fire (few charcoals).

From ca. 5700 cal. BP, pollen based climate values also shows dramatic precipitation decrease both annually and during late spring $\left(\mathrm{P}_{\text {May-Jun }}=135 \mathrm{~mm}\right)$. This dry phase may induce cultural changes across Middle East (Roberts et al., 2011). Climate mechanism behind this phase remains unclear. According to Joannin et al. (2014), dry phases observed during the Mid (and Late) Holocene in Armenia may be related to centennial-scale variation of Westerly activity (NAO-like). This mechanism would imply stronger Siberian High to block depression to come through the Lesser Caucasus. 


\section{Conclusion}

The study of Vanevan Peat (1919 m a.s.I.) provides a record of past environmental changes taking place in and around Lake Sevan. Modern peat exploitation by surface milling caused the disappearance of the uppermost part of the core, which fortunately revealed a well preserved core section covering approximately 8000 to 5000 cal. BP. Sampling resolution and robust age model documents vegetation history in Armenia, where studies are particularly rare. The present investigation therefore completes the pollen study at Zarishat fern (Joannin et al., 2014), by documenting open-land vegetation up to ca. 7700 cal. BP, followed by a more forested landscape during the Mid Holocene (up to ca. 5700 cal. BP) than today and ending again with open-land vegetation (up to the record stop, i.e. 5100 cal. BP). These successive phases are evidenced through records of pollen-based terrestrial vegetation, climate reconstruction and non-terrestrial vegetation, the last being related to Lake Sevan water-level changes.

This delayed afforestation recorded in Vanevan peat is a pattern that has now been recognized widely through the Near-East indicating dry climate conditions. Arid climate is linked to low late spring precipitation corroborated by estimated low MayJune precipitation compared to annual precipitation. Strong Siberian Highs most probably blocked westerly winds (and precipitation) and caused dry late springs. During the following two thousand years, a more forested landscape is recorded while Vanevan area is progressively colonised by aquatic vegetation reaching an optimum, between ca. 7240 and 7060 cal. BP. From ca. 7670 cal. BP, Cerealia-type is recorded but without other indication such as forest openings, more evidences are needed to certify that farmers were living on the lakeshores at this epoch.

Afforestation and Poaceae developments rely on strong climate changes. Pollenbased climate reconstruction show increasing annual precipitation mainly driven by late spring precipitation. This marks the onset of lower seasonality, related to a change in the climate mechanisms equilibrium; reinforcement of the Westerlies and less active Siberian Highs.

Strong palaeoecological changes are recorded from ca. 5700 to ca. 5100 cal. BP resulting in the Poaceae increasing amount. This pollen grain could be provided both by open-land grassland and by local vegetation (i.e. Phragmites) that are indubitably to develop at a time of shallowing related to a Lake Sevan regressive phase. These high Poaceae percentage, coincide with increase in fire activity which seems to affect only one source of local bio-fuel, to which Cyperaceae and Phragmites are good candidates. Disappearance of human activity pollen indicators claims for no human impact on this fire activity which is link to drying climate conditions. From ca. 5700 cal. BP, pollen-based climate reconstruction also shows precipitation decrease both annually and during late spring $\left(P_{\text {May-Jun }}=134 \mathrm{~mm}\right)$. This dry phase previously observed in Armenia may be related to centennial-scale variation of Westerly activity (NAO-like). This mechanism would imply stronger Siberian Highs to block depression to come through the Lesser Caucasus.

These conclusions mainly link palaeoenvironmental changes in Vanevan wetland as well as in surroundings of Lake Sevan with climate hypothesis. Human impact for the pre-time Bronze Age is indeed not well documented by our study nor by archeological studies. However, scarcity of such studies is a matter of concern and one cannot consider the understanding level of research on human activities enough 
to fully conclude yet. Volcanism is another hypothesis possible, but has not been discussed here because of information lacking. Lake Sevan is indeed surrounded by many volcanoes, some are expected to be Holocene (Karakhanian et al., 2003). This hypothesis relies on basalt flows that possibly affect lake-level by damming the outlet. Whether the climate explanation appears satisfactory due to similar characteristics throughout the Near-East, more studies from Sevan area with a wider disciplinary spectrum (archeology, volcanism) are mandatory to precisely balance relative effects of all those components on lake-level changes and environmental and human issues.

\section{Acknowledgment}

Financial support for this study was provided by the French-Armenian International Associated Laboratory HEMHA (Humans and environments in mountainous habitats, the case of Armenia) supervised by $C$. Chataigner and P. Avetisyan. This program between Armenia and France is founded by the French National Centre for Scientific Research (CNRS). We thank the University of Rennes1 for financial support. We thank Caucasus programme of French ministry of foreign tasks. We thank the two anonymous reviewers for their comments. We thank L. Millet (Univ. Franche-Comte) who conducted an investigation on chironomids assemblages which revealed only few specimens. We are grateful to S. Muller (Univ. Montpellier 2) for landing us the corer. We thank M. Karapetyan for the French translation of referencies in Russian. This is an ISEM contribution $n^{\circ}$ ISEM 2015-045.

\section{References}

Aleman, J.C., Blarquez, O., Bentaleb, I., Bonté, P., Brossier, B., Carcaillet, C., Gond, V., Gourlet-Fleury, S., Kpolita, A., Lefèvre, I., Oslisly, R., Power, M.J., Yongo, O., Bremond, L., Favier, C., 2013. Tracking land-use with sedimentary charcoal in the tropics. The Holocene, 23 (12), 1853-1862.

Badalyan, R., Harutyunyan, A., Chataigner, C., Le Mort, F., Brochier, J.-E., Balasescu, A., Radu, V., Hovsepyan, R., 2010. The settlement of AknashenKhatunarkh, a Neolithic site in the Ararat Plain (Armenia): excavation results 20042009. TÜBA-AR, 185-218.

Baghdasaryan, A.B., 1958. Klimat Armyanskoy SSR. Yerevan, 108-118.

Berg, L.S., 1950. Natural Regions of the U.S.S.R. Macmillan, New York.

Behre, K.-E., 1981. The interpretation of anthropogenic indicators in pollen diagrams. Pollen et Spores 23 (2), 225-243.

Behre, K.-E., 1990. Some reflections on anthropogenic indicators and the record of prehistoric occupation phases in pollen diagrams from the Near East. In: Bottema, S., Entjes-Nieborg, G., Van Zeist W. (Eds.), Man's role in the shaping of the Eastern Mediterranean Landscape. A.A. Balkema, Rotterdam, pp. 219-230. 
Beug, H.-J., 2004. Leitfaden der Pollenbestimmung für Mitteleuropa und angrenzende Gebiete. Pfeil, Munich.

Blaauw, M., 2010. Methods and code for 'classical' age-modelling of radiocarbon sequences. Quaternary Geochronology 5, 512-518.

Bohn, U., Gollub, G., Hettwer, C., 2000. Karte der natürlichen Vegetation Europas.Bundesamt für Naturschutz Federal Agency for Nature Conservation, BohnBadGodesberg.

Bottema, S., 1975. The interpretation of pollen spectra from prehistoric settlements (with special attention to Liguliflorae). Palaeohistoria 17, 17-35.

Bottema, S., 1986. A late Quaternary pollen diagram from Lake Urmia (northwestern Iran). Review of Palaeobotany and Palynology 47, 241-261.

Brun, C., 2011. Anthropogenic indicators in pollen diagrams in eastern France: a critical review. Vegetation history and archaeobotany 20 (2), 135-142.

Carcaillet, C., Bouvier, M., Fréchette, B., Larouche, A.C., Richard, P.J.H., 2001. Comparison of pollen-slide and sieving methods in lacustrine charcoal analyses for local and regional fire history. The Holocene 11, 467-476.

Chataigner, C., 2007. La néolithisation de l'Arménie. In: Djindjian F. (Ed.), Arménie des origines à la christianisation. Les Dossiers d'Archéologie 321, pp. 30-35.

Chataigner, C., Gasparyan, B., Montoya, C., Arimura, M., Melikyan, V., Liagre, J., Petrosyan, A., Ghukasyan, R., Colonge, D., Fourloubey, C., Arakelyan, D., Astruc, L., Nahapetyan, S., Hovsepyan, R., Balasescu, A., Tomé, C., Radu, V., 2012. From the Late Upper Paleolithic to the Neolithic in north-western Armenia: preliminary results. In: Avetisyan P., Bobokhyan A. (Eds), Archaeology of Armenia in regional context Proceedings of the International Conference dedicated to the $50^{\text {th }}$ Anniversary of the Institute of Archaeology and Ethnography. Gitutyun, Yerevan, pp. 52-63.

Chataigner, C., Gratuze, B., 2014. New data on the exploitation of obsidian in the Southern Caucasus (Armenia, Georgia) and eastern Turkey, Part 2: Obsidian procurement from the Upper Palaeolithic to the Late Bronze Age. Archaeometry 56 (2), 569-577.

Chen, F., Yu, Z., Yang, M., Ito, E., Wang, S., Madsen, D. B., Huang, X., Zhao, Y., Satof, T., Birks, H.J. B., Boomer, I., Chen, J., An, C., Wünnemann, B., 2008. Holocene moisture evolution in arid central Asia and its out-of-phase relationship with Asian monsoon history. Quaternary Science Reviews 27, 351-364.

Chorbajian, S., 2006. Deforestation in the Republic of Armenia: a Human and Environmental Crisis. New York.

Connor, S.E., 2011. A Promethean Legacy: Late Quaternary Vegetation History of Southern Georgia, the Caucasus. Peeters, Louvain. 
Connor, S.E., Kvavadze, E.V., 2008. Modelling late Quaternary changes in plant distribution, vegetation and climate using pollen data from Georgia, Caucasus. Journal of Biogeography 36 (3), 529-545.

Connor, S.E., Thomas, I., Kvavadze, E.V, Arabuli, G.J., Avakov, G., Sagona, A., 2004. A survey modern pollen and vegetation along an altitudinal transect in southern Georgia, Caucasus region. Review of Palaeobotany and Palynology 129, 229-250.

Connor, S.E., Ross, S.A., Sobotkova, A, Herries, A.I.R., Mooney, S.D., Longford, C., Iliev, I., 2013. Environmental conditions in the SE Balkans since the Last Glacial Maximum and their influence on the spread of agriculture into Europe. Quaternary Science Reviews 68, 200-215.

Cook, C.D.K., 1990. Aquatic Plant Book. SPB Academic Publishing, The Hague.

Djamali, M., de Beaulieu, J.-L., Shah-hosseini, M., Andrieu-Ponel, V., Ponel, P., Amini, A., Akhani, H., Leroy, S.A.G., Stevens, L., Lahijani, H., Brewer, S., 2008. A late Pleistocene long pollen record from Lake Urmia, NW Iran. Quaternary Research 69 (3), 413-420.

Djamali, M., Akhani, H., Andrieu-Ponel, V., Braconnot, P., Brewer, S., de Beaulieu, J.-L., Fleitmann, D., Fleury, J., Gasse, F., Guibal, F., Jackson, S.T., Lézine, A.-M., Médail, F., Ponel, P., Roberts, N., Stevens, L.R., 2010. Indian summer monsoon variations could have affected the early-Holocene woodland expansion in the Near East. The Holocene 20(5), 813-820.

Fægri, K., Iversen, J., 1989. Textbook of Pollen Analysis. Fourth ed. Wiley, Chichester.

Fare, A., Dutartre, A., Rebillard, J.-P., 2001. Les principaux végétaux aquatiques du Sud-Ouest de la France. Agence de l'eau Adour Garonne - Cemagref.

Filipova-Marinova, M., Pavlov, D., Coolen, M., Giosan, L., 2013. First high-resolution marinopalynological stratigraphy of Late Quaternary sediments from the central part of the Bulgarian Black Sea area. Quaternary International 293, 170-183.

Frederiksen, S., Petersen G., 1998. A taxonomic revision of Secale (Triticeae, Poaceae). Nordic Journal of Botany 18 (4), 399-420.

Goeury, C., 1997. GpalWin: gestion, traitement et représentation de la paléoécologie. XVe Symposium de l'APLF, Lyon, France, p. 31.

Guiot, J., 1990. Methodology of the last climatic cycle reconstruction in France from pollen data. Palaeogeography Palaeochmatology Palaeoecology 80, 49-69.

Gulakyan, S.Z., Wilkinson, I.P., 2002. The influence of earthquakes on large lacustrine ecosystems, with particular emphasis on Lake Sevan, Armenia. Hydrobiologia 472, 123-130. 
Hall, S.A., 1981. Deteriorated pollen grains and the interpretation of Quaternary pollen diagrams. Review of Palaeobotany and Palynology 32, 193-206.

Hammer, Ø., Harper, D.A.T., Ryan, P. D., 2001. PAST: Paleontological Statistics Software Package for Education and Data Analysis. Palaeontologia Electronica 4 (1).

Haslam, S., Sinker, C., Wolseley, P., 1982. British Water Plants. Ed. Field Studies, the journal of the Field Studies Council.

Havinga, A.J., 1984. A 20-year experimental investigation into the differential corrosion susceptibility of pollen and spores in various soil types. Pollen et Spores 26 (3-4), 541-558.

Higuera, P.E., Peters, M.E., Brubaker, L.B., Gavin, D.G., 2007. Understanding the origin and analysis of sediment-charcoal records with a simulation model. Quaternary Science Reviews 26, 1790-1809.

Huntley, B., 2012. Reconstructing palaeoclimates from biological proxies: some often overlooked sources of uncertainty. Quaternary Science Reviews 31, 1-16.

Jenderedjian, K., 2005. Peatlands of Armenia. Stapfia 85, zugleich Kataloge der OÖ. Landesmuseen Neue Serie 35, 323-333

Joannin, S., Vannière, B., Galop, D., Peyron, O., Haas, J.N., Gilli, A., Chapron, E., Wirth, S., Anselmetti, F., Desmet, M., Magny, M., 2013. Climate and vegetation changes during the Lateglacial and early-middle Holocene at Lake Ledro (southern Alps, Italy). Climate of the Past 9, 913-933.

Joannin, S., Ali, A.A., Ollivier, V., Roiron, P., Peyron, O., Chevaux, S., Nahapetyan, S., Tozalakyan, P., Karakhanyan, A., Chataigner, C., 2014. Vegetation, fire and climate history of the Lesser Caucasus: a new Holocene record from Zarishat fen (Armenia). Journal of Quaternary Science 29 (1), 70-82.

Karakhanian, A., Jrbashyan, R., Trifonov, V., Philip, H., Arakelian, S., Avagyan, A., Baghdassaryan, H., Davtian, V., Ghoukassyan, Yu., 2003. Volcanic hazards in the region of the Armenian nuclear power plant. Journal of Volcanology and Geothermal Research 126 (1-2), 31-62.

Lebreton, V., Messager, E., Marquer, L., Renault-Miskovsky, J., 2010. A neotaphonomic experiment in pollen oxidation and its implications for archaeopalynology. Review of Palaeobotany and Palynology 162, 29-38.

Leroy, S.A.G., Tudryn, A., Chalié, F., Lopez-Merino, L., Gasse, F., 2013. From the Allerød to the mid-Holocene: palynological evidence from the south basin of the Caspian Sea. Quaternary Science Reviews 78, 77-97.

Leroy, S.A.G., Lopez-Merino, L., Tudryn, A., Chalié F., Gasse F., 2014. Late Pleistocene and Holocene palaeoenvironments in and around the middle Caspian basin as reconstructed from a deep-sea core. Quaternary Science Reviews 101, 91110. 
Leroyer, C., Coubray, S., Allenet, G., Perrière, J., Pernaud; J.-M., 2011. Vegetation dynamics, human impact and exploitation patterns in the Paris basin through the Holocene: palynology vs. anthracology. Saguntun extra 11, 80-82.

Lind, D., Taslakyan, L., 2005. Restoring the Fallen Blue Sky: Management issues and environmental legislation for Lake Sevan, Armenia. Yerevan.

Litt, T., Krastel, S., Sturm, M., Kipfer, R., Örcen, S., Heumann, G., Franz, S.O., Ülgen, U.B., Niessen, F., 2009. 'PALEOVAN', International Continental Scientific Drilling Program (ICDP): site survey results and perspectives. Quaternary Science Reviews 28 (15-16), 1555-1567.

Mathis, M., Sorrel, P., Klotz, S., Huang, X., Oberhänsli, H., 2014. Regional vegetation patterns at lake Son Kul reveal Holocene climatic variability in central Tien Shan (Kyrgyzstan, Central Asia). Quaternary Science Reviews 89, 169-185.

Messager, E., Belmecheri, S., Von Grafenstein, U., Nomade, S., Ollivier, V., Voinchet,P., Puaud, S., Courtin-Nomade, A., Guillou, H., Mgeladze, A., Dumoulin, J.P., Mazuy, A., Lordkipanidze, D., 2013. Late Quaternary record of the vegetation and catchment-related changes from Lake Paravani (Javakheti, South Caucasus).

Quaternary Science Reviews 77, 125-140.

Meybeck, M., 1995. Les lacs et leur bassin. In : Pourriot, R., Meybeck, M. (Eds.), Limnologie générale. Masson, Paris, pp. 6-60.

Meybeck, M., Akopian, M., Andreassian, V., 1997. What happened to lake Sevan? SIL News 23, 7-10.

Moreno-Sanchez, R., Sayadyan, H.Y., 2005. Evaluation of the forest cover in Armenia. International Forestry Review 7(2), 113-127.

NOAA,ttp://ftp.ncdc.noaa.gov/pub/data/paleo/paleolimnology/lakelevels/former_ussr/l ake_descriptions/textfiles/sevan.txt

Ollivier, V., Nahapetyan, S., Roiron, P., Gabrielyan, I., Gasparyan, B., Chataigner, C., Joannin, S., Cornée, J.-J., Guillou, H., Scaillet, S., Munch, P., Krijgsman, W., 2010. Quaternary volcano-lacustrine patterns and paleobotanical data in South Armenia. Quaternary International 223-224, 312-326.

Ollivier, V., Joannin, S., Roiron, P., Nahapetyan, S., Chataigner, C., 2011. Travertinization and Holocene morphogenesis in Armenia: A reading grid of rapid climatic changes impact on the landscape and societies between 9500-4000 cal. BP in the Circumcaspian regions? European Archaeologist 36: 26-31.

Peyron, O., Guiot, J., Cheddadi, R., Tarasov, P., Reille, M., Beaulieu, J.-L. de, Bottema, S., Andrieu, V., 1998. Climatic reconstruction in Europe for 18,000 yr B.P. from pollen data. Quaternary Research 49 (2), 183-196.

Reille, M., 1992-1998. Pollen et Spores d'Europe et d'Afrique du Nord. Laboratoire de Botanique Historique et Palynologie. U.R.A. C.N.R.S. 1152, Marseille. 
Reimer, P.J., Baillie, M.G.L., Bard, E., Bayliss, A., Beck, J.W., Blackwell, P.G., Bronk Ramsey, C., Buck, C.E., Burr, G.S., Edwards, R.L., Friedrich, M., Grootes, P.M., Guilderson, T.P., Hajdas, I., Heaton, T.J., Hogg, A.G., Hughen, K.A., Kaiser, K.F., Kromer, B., McCormac, F.G., Manning, S.W., Reimer, R.W., Richards, D.A., Southon, J.R., Talamo, S., Turney, C.S.M., van der Plicht, J., Weyhenmeyer, C.E., 2009. INTCAL09 and MARINE09 radiocarbon age calibration curves, 0-50,000 years cal BP. Radiocarbon 51, 1111-1150.

Roberts, N., Eastwood ,W.J., Kuzucuoğlu, C., Fiorentino, G., Caracuta ,V., 2011. Climatic, vegetation and cultural change in the eastern Mediterranean during the midHolocene environmental transition. The Holocene 21 (1), 147-162.

Roberts, N., Reed, J.M., Leng, M.J., Kuzucuoğlu, C., Fontugne, M., Bertaux, J., Woldring, H., Bottema, S., Black, S., Hunt, E., Karabıyıkoğlu, M., 2001. The tempo of Holocene climatic change in the eastern Mediterranean region: new high-resolution craterlake sediment data from central Turkey. The Holocene 11, 721-736.

Sayadyan, H.Y., 2011. Valuation of mountain forests: case study Armenia. Annals of agrarian science. Republic of Georgia. Vol.9. No.1., pp.144-148.

Sayadyan, Y.V., 1978. Postglacial times in Armenia and adjacent regions. Studia Geomorphologica Carpatho-Balcanica (Krakow) XII, 77-93.

Sayadyan, Y.V. 2002. Natural specific features of Lake Sevan and its basin, in Biscione, Hmayakyan, Parmegiani eds.: The North-Eastern Frontier. Urartians and non-Urartians in the Sevan Lake Basin, Roma, 19-36.

Sayadyan, Y.V., 2009. The newest geological history of Armenia. Gitutun publish. Nat. Acad. Sciences, Yerevan, 357p. [in Russian]

Sayadyan, Y.V., Aleshinskaya, Z. V., 1991. History of Lakes Sevan, Issyk-Kul, Balkhash, Zaisan, and Aral (Nauka, Leningrad, 1991), pp. 38-49. [in Russian]

Sayadyan, Y.V., Aleshinskaya, Z.V., Khanzadyan, E.V., 1977. Late glacial deposits and archaeology of the Sevan Lake. In: Sayadyan, Y..V. (Ed.), Geologiya chetvertichnogo perioda (Pleistotsen) (Geology of the Quaternary period (Pleistocene)), Akad. Nauk Arm. SSR, Yerevan, pp. 91-109. [in Russian]

Shumilovskikh, L.S., Tarasov ,P., Arz, H.W., Fleitmann, D., Marret, F., Nowaczyk, N., Plessen, B., Schlütz, F., Behling, H., 2012. Vegetation and environmental dynamics in the southern Black Sea region since $18 \mathrm{kyr}$ BP derived from the marine core 22GC3. Palaeogeography, Palaeoclimatology, Palaeoecology 337-338, 177-193.

Stevens, L.R., Wright, H.E., Ito, E., 2001. Proposed changes in seasonality of climate during the Lateglacial and Holocene at Lake Zeribar, Iran. The Holocene 11 (6), 747755. 
Stevens, L.R., Ito, E., Schwalb, A., Wright, H.E., 2006. Timing of atmospheric precipitation in the Zagros Mountains inferred from a multi-proxy record from Lake Mirabad, Iran. Quaternary Research 66, 494-500.

Sugita, S., 1993. A model of pollen source area for an entire lake surface. Quaternary Research 39, 239-244.

Sugita, S., Gaillard, M.-J., Broström, A., 1999. Landscape openness and pollen records: a simulation approach. The Holocene 9 (4), 409-421.

Takhtajyan, A.L., 1941. Botaniko-geograficheskiy ocherk Armenii (Botanicalgeographic overview of Armenia). Trudi Botanicheskogo Instituta Armyanskogo filiala akademii nauk SSSR, Work papers of Institute of Botany of Armenian Academy of Sciences/ Branch of USSR Academy of Sciences 2, 180 p. [in Russian]

Telford, R.J., Birks, H.J.B., 2005. The secret assumption of transfer functions: problems with spatial autocorrelation in evaluating model performance. Quaternary Science Reviews 24, 2173-2179.

Tumanyan, M.R., 1971. On the history of lake Sevan basin vegetation in holocene (K istorii rastitelnosti baseyna ozera sEvan $v$ Golocene), Academy of Sciences of Armenian SSR, Biological journal, T.XXIV, 11, 57-61. [in Russian]

Tumajanov, I.I., Tumanyan, M.R. 1973.New data on the history of forest vegetation in Masrik plain in Holocene. Academy of Sciences of Armenian SSR, Biological journal, T.XXVI, 12, .24-28. [in Russian]

Turner, R., Roberts, N., Eastwood, W.J., Jenkins, E., Rosen, A., 2010. Fire, climate and the origins of agriculture: micro-charcoal records of biomass burning during the last glacial-interglacial transition in Southwest Asia. Journal of Quaternary Science 25 (3), 371-386.

Tweddle, J.C., Edwards, K.J., Fieller, N.R.J., 2005. Multivariate statistical and other approaches for the separation of cereal from wild Poaceae pollen using a large Holocene dataset. Vegetation History and Archaeobotany 14 (1), 15-30.

Van Geel, B., Aptroot, A., 2006. Fossil ascomycetes in Quaternary deposits. Nova Hedwigia 82, 313-329

Van Zeist, W., Bottema, S., 1977. Palynological investigations in western Iran. Palaeohistoria 24, 19-85.

Van Zeist, W., Woldring, H., 1978. A Postglacial pollen diagram from Lake Van in East Anatolia. Review of Palaeobotany and Palynology 26, 249-76.

Van Zeist, W., Woldring, H., Stapert, D., 1975. Late Quaternary vegetation and climate of southwestern Turkey. Palaeohistoria 17, 53-143.

Wick, L., Lemcke, G., Sturm, M., 2003. Evidence of Lateglacial and Holocene climatic change and human impact in eastern Anatolia: high resolution pollen, charcoal, 
isotopic and geochemical records from the laminated sediments of Lake Van, Turkey. The Holocene 13 (5), 665-675.

Wright Jr., H.E., Ammann, B., Stefanova, I., Atanassova, J., Margalitadze, N., Wick, L., Blyakharchuk, T., 2003. Lateglacial and early-Holocene dry climates from the Balkan peninsula to Southern Siberia. In : Tonkov, S.B. (ed.), Aspects of Palynology and Palaeoecology. Pensoft Publishers, Sofia-Moscow, pp. 127-136.

Zazanashvili, N., Gagnidze, R., Nakhutsrishvili, G., 2000. Main types of vegetation zonation on the mountains of the Caucasus. Acta Phytogeographica Suecica, 85, 716. 


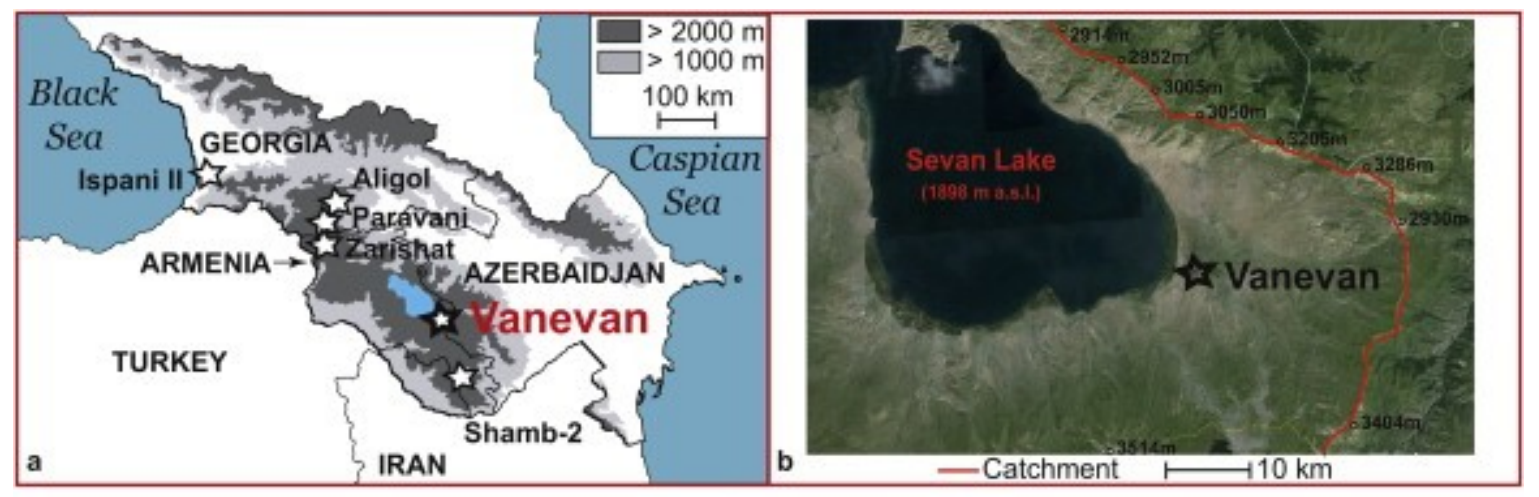

Fig. 1. a) Location map of Caucasus and sites cited in the text; b) location map of Vanevan Site.

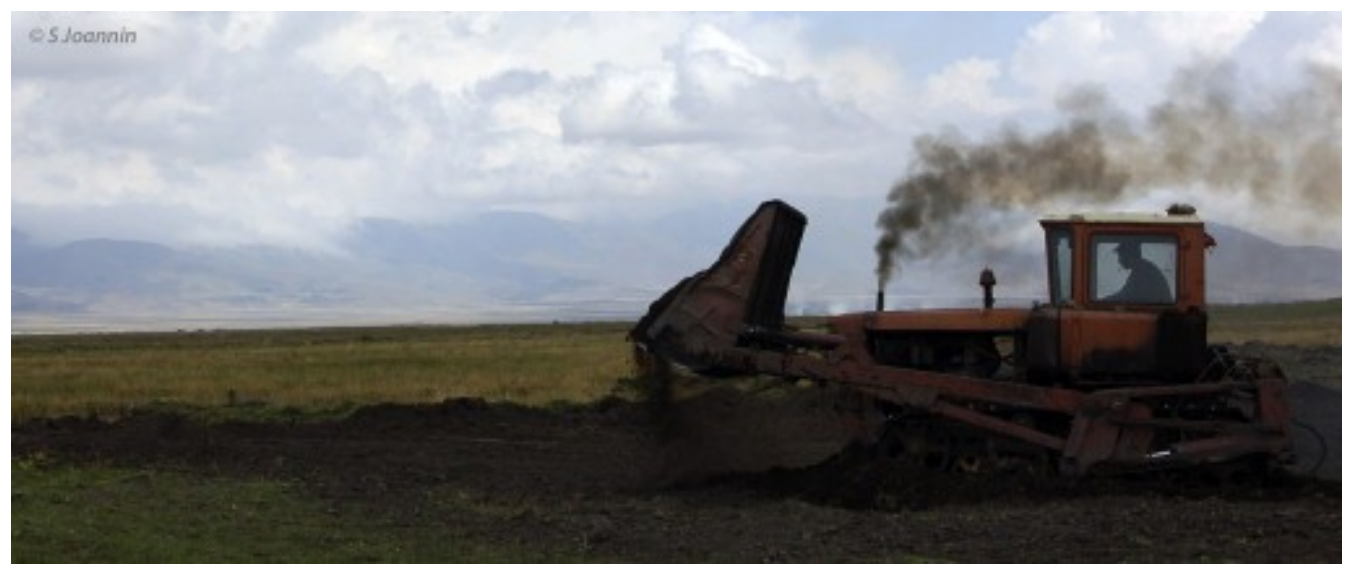

Fig. 2. Peat exploitation by mechanical milling of surface at Vanevan (2011).

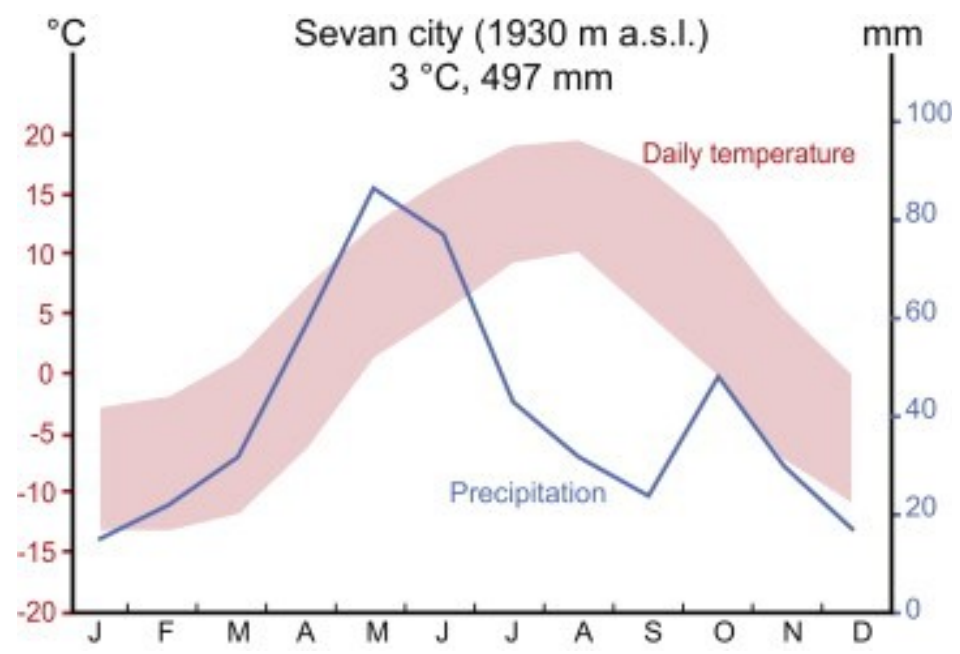

Fig. 3. Ombrothermic diagram of the meteorological station of Sevan, ca. $70 \mathrm{~km}$ from Vanevan peat. Records of minimum and maximum mean daily temperature and precipitation span the last 30 years. 


\begin{tabular}{|c|c|c|c|}
\hline Unit & $\begin{array}{l}\text { Formation } \\
\text { complexe }\end{array}$ & $\begin{array}{l}\text { Vegetation type and } \\
\text { main taxa observed }\end{array}$ & Taxa list \\
\hline M11 & Steppes & $\begin{array}{c}\text { Pre- and } \\
\text { Transcaucasian feather } \\
\text { grass steppes }\end{array}$ & $\begin{array}{l}\text { Stipa tirsa, S. pulcherrima, S. daghestanica, S. transcaucasica, } \\
\text { S. araxensis, S. pontica, S. holosericea, S. hohenackeriana with } \\
\text { Elytrigia gracillima, Astragalus haesitabundus, A. gjunaicus, } \\
\text { Medicago daghestanica, Onobrychis transcaucasica, Linaria } \\
\text { megrica and Bothriochloa ischaemum-steppes with Onobrychis } \\
\text { ruprechtii, O. kachetica, Salvia daghestanica, Hyssopus } \\
\text { officinalis subsp. angustifolius, Medicago caerulea, Polygala } \\
\text { transcaucasica, alternating with tomillares (Thymus } \\
\text { daghestanicus, T. karamarjanicus, T. tiflisiensis, Thymus } \\
\text { kotschyanus, Scutellaria orientalis) and thorn-cushion } \\
\text { communities (Astragalus aureus, A. denudatus, A. } \\
\text { microcephalus, A. uraniolimneus) }\end{array}$ \\
\hline
\end{tabular}

\begin{tabular}{|c|c|c|c|}
\hline M4 & Steppes & $\begin{array}{l}\text { Transcaucasian } \\
\text { altimontane herb-grass- } \\
\text { and meadow steppes }\end{array}$ & $\begin{array}{l}\text { Meadow steppes and the mountain steppes (Stipa tirsa, S. } \\
\text { pulcherrima, Festuca ovina, Carex humilis, Poa densa, Bromus } \\
\text { variegatus, Onobrychis altissima, O. transcaucasica, Serratula } \\
\text { biebersteiniana, Prangos ferulacea, Aster ibericus) with } \\
\text { Medicago papillosa, Astragalus hyalolepis, Linaria kurdica, } \\
\text { Salvia armeniaca, alternating with thorn-cushion communities } \\
\text { (Astragalus aureus, A. microcephalus, A. lagopoides) and } \\
\text { tomillares (Thymus rariflorus, T. kotschyanus, Scutellaria } \\
\text { orientalis) }\end{array}$ \\
\hline
\end{tabular}

\begin{tabular}{llc}
\hline C46 & $\begin{array}{l}\text { Montane } \\
\text { open }\end{array}$ & $\begin{array}{c}\text { Open krummholz } \\
\text { forests and open } \\
\text { woodlands }\end{array}$ \\
woodlands
\end{tabular}

Endemic trees species (Quercus macranthera, Acer trautvetteri, Betula litwinowii), schrub (Juniperus communis subsp. hemisphaerica, J. sabina), grasslands (Festuca woronowii, Bromus variegatus, Anemone fasciculata) with Trifolium bordzilowsky, partly tall-forb communities (Milium effusum, Gagea orientalis, Lilium armenum), alternating with dry grasslands (Festuca ovina, Carex humilis) with Medicago papillosa, true steppes (Festuca valesiaca, Stipa tirsa, S. pulcherrima), partly with thorn-cushion mountain vegetation (Astragalus aureus, A. lagopoides)

\begin{tabular}{lll}
\hline B58 Alpine & Alpine grasslands & Festuca woronowii, Nardus stricta, Carex tristis, Bellardiochloa \\
vegetation & polychroa, Scabiosa caucasica with Agrostis lazica, Bromus \\
& variegatus subsp. villosulus and small herb communities (Carum \\
& caucasicum, Campanula tridentata) with Gentiana pontica, \\
& alternating with shrub (Rhododendron caucasicum), rock and \\
& scree vegetation
\end{tabular}

K33 Xerophytic Transcaucasian colline- Juniperus polycarpos, J. foetidissima, partly in combination with coniferous montane juniper open Pistacia mutica

forests and woodlands and Pistacia scrub mutica open woodlands

\section{Table 1:}

Description of formation complexes, units, vegetation types and taxa list around Lake Sevan (after Bohn et al., 2000). 


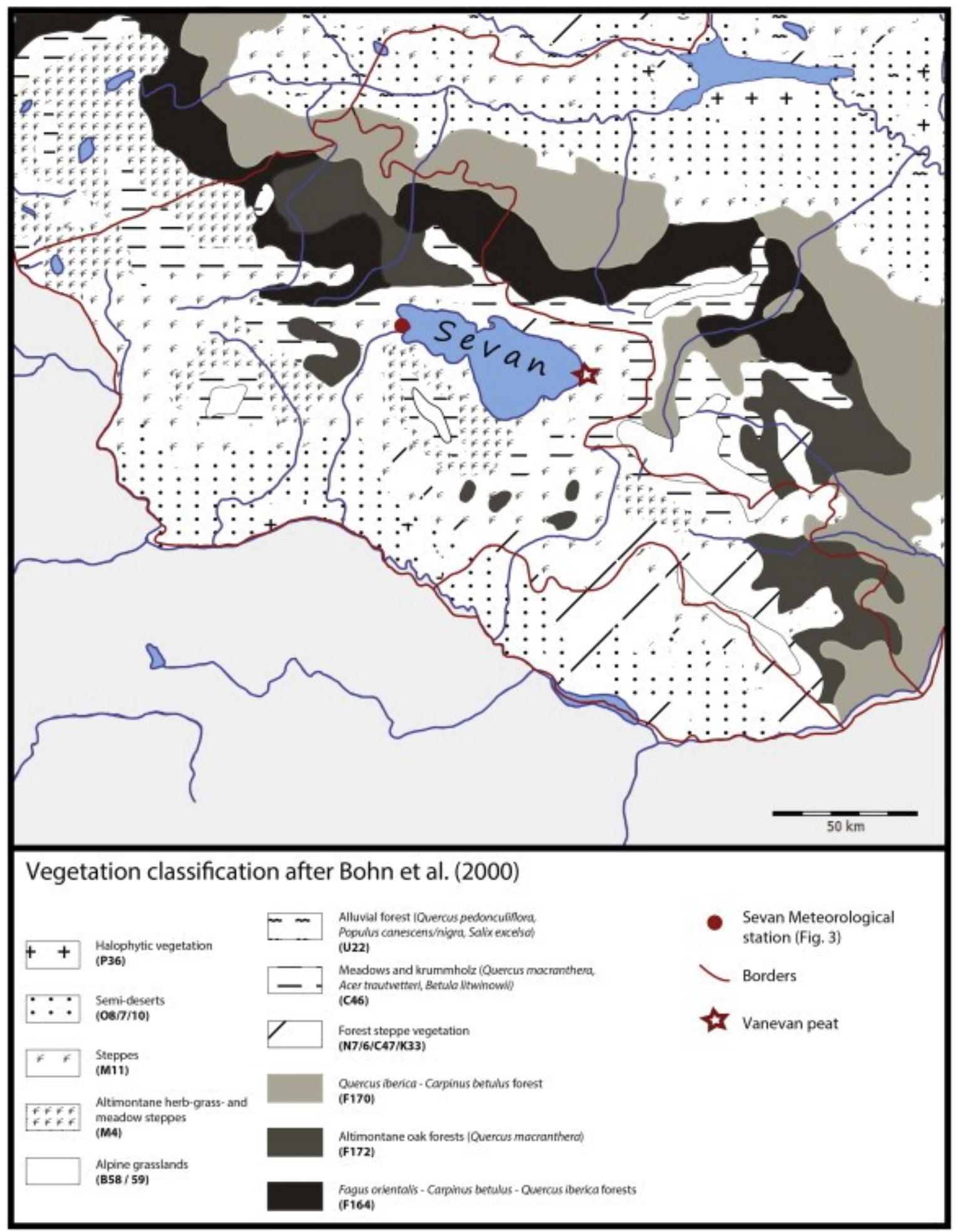

Fig. 4. Vegetation map of Lesser Caucasus (after Bohn et al., 2000). 


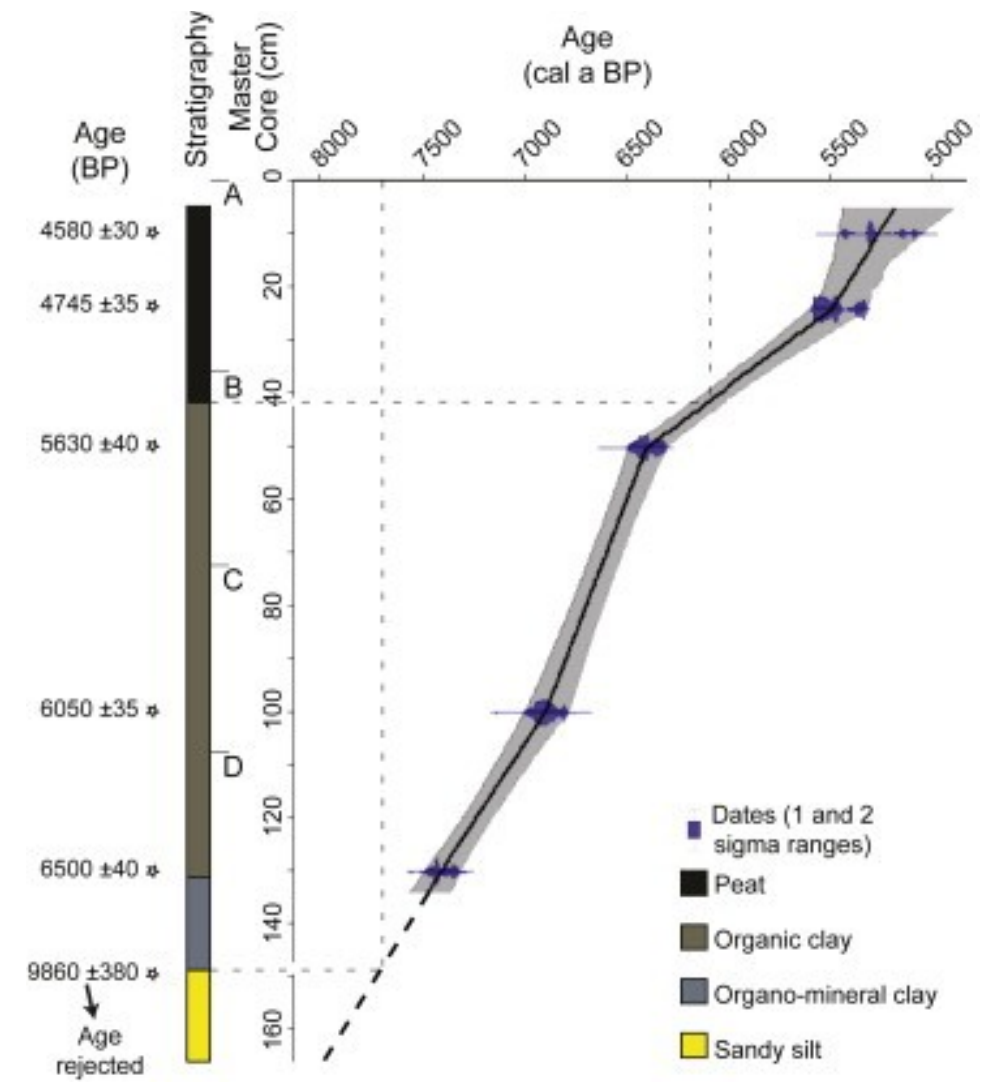

Fig. 5. Lithology of cores A to D and age-depth model based on calibrated radiocarbon ages (dots with 2-sigma errors) (AMS, see Table 2) from Vanevan. 


\begin{tabular}{llllll}
\hline Sample ID & Lab. code & Material & $\begin{array}{l}\text { AMS }{ }^{14} \mathrm{C} \\
\text { age BP }\end{array}$ & $\begin{array}{l}\text { Depth } \\
\text { MC }(\mathrm{cm})\end{array}$ \\
\hline A-10.5 & Ly-10435 & Terrestrial organic & $4580 \pm 30$ & 10.5 & $5066-5181$ \\
\hline A-24.5 & Poz-46337 & Terrestrial organic & $4745 \pm 35$ & 24.5 & $5328-5586$ \\
\hline B-14.5 & Poz-46338 & Terrestrial organic & $5630 \pm 40$ & 50.5 & $6314-6487$ \\
\hline C-28.5 & Poz-46340 & Terrestrial organic & $6050 \pm 35$ & 100.5 & $6795-6991$ \\
\hline D-22.5 & Poz-46341 & Terrestrial organic & $6500 \pm 40$ & 130.5 & $7319-7483$ \\
\hline D-42.5 ${ }^{*}$ & Poz-52961 & Bulk & $9860 \pm 380$ & 150.5 & $10298-12530$ \\
${ }^{*}$ Age rejected (see text) & & & &
\end{tabular}

$\underline{\text { Table 2: }}$

AMS-radiocarbon dates with $2 \sigma$ range of calibration from cores of Vanevan peat. $M C=$ master core.

$\underline{\text { Figure } 6}$ : Pollen diagram against depth showing percentages of pollen taxa. Pollen zones are based on Past software. Shrubs: Vitis, Rosaceae, Rhamnaceae. Varia 1: Haplophyllum, Erodium, Calystegia, Symphitum,Saxifraga aizoides type, Cuscuta, Matthiola, Onagraceae, Colchicum, Primulaceae. Varia 2: Teucrium, Sanguisorba officinalis, Rumex aquaticus type, Lythrum. Algae: B=Botryococcus; P=Pediastrum. LPAZ: Local Pollen Assemblage Zones, AP: Arboreal Pollen, NAP: Non Arboreal Pollen. Pollen values lower than $1 \%$ are represented by dots.

Figure 7: Pollen diagram against age showing percentages of main pollen taxa or group of taxa. Depth and pollen zones from Figure 6 are reported. Quantitative estimates of temperature and precipitation and macrocharcoal concentration are shown. Red and green stars indicate present day MTCO and winter and late spring (May-June) precipitation, respectively. Yellow and blue shadings are used to represent arid and humid phases, respectively.

Figure 8: Comparison of paleorecords from Zeribar (A; Stevens et al., 2001), Mirabad (B; Stevens et al., 2006), 22GC3 (C; Shumilovskikh et al., 2012), Paravani (D; Messager et al., 2013), Zarishat (E; Joannin et al., 2014), Vanevan (F; this study), Ispani II (G; Connor and Kvavadze, 2008) and Central Asia [biotic (e.g. pollen and diatoms) and abiotic proxies (e.g. $\delta 18 \mathrm{O}$ and lake-level); $\mathrm{H}$; Chen et al., 2008]; including Lake Van, Wick et al., 2003). Macrocharcoal concentration is given together with length-to-width ratio. Yellow and blue shadings are used to represent arid and humid phases, respectively. 
$\underline{\text { Figure } 6}$

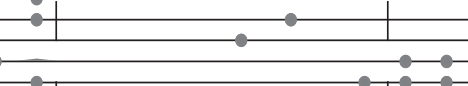




\section{$\underline{\text { Figure } 8}$}

Arid Central Asia (Data compilation ranging from $43-117^{\circ} \mathrm{E}$ ) Moisture Index

Ispani II, Georgia $\left(41^{\circ} \mathrm{N}, 41^{\circ} \mathrm{E}\right)$

Precipitation $(\mathrm{mm} / \mathrm{yr})$

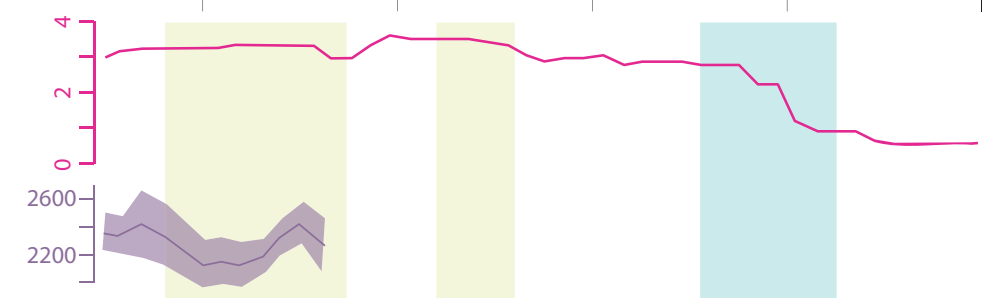

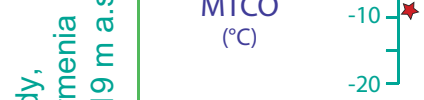
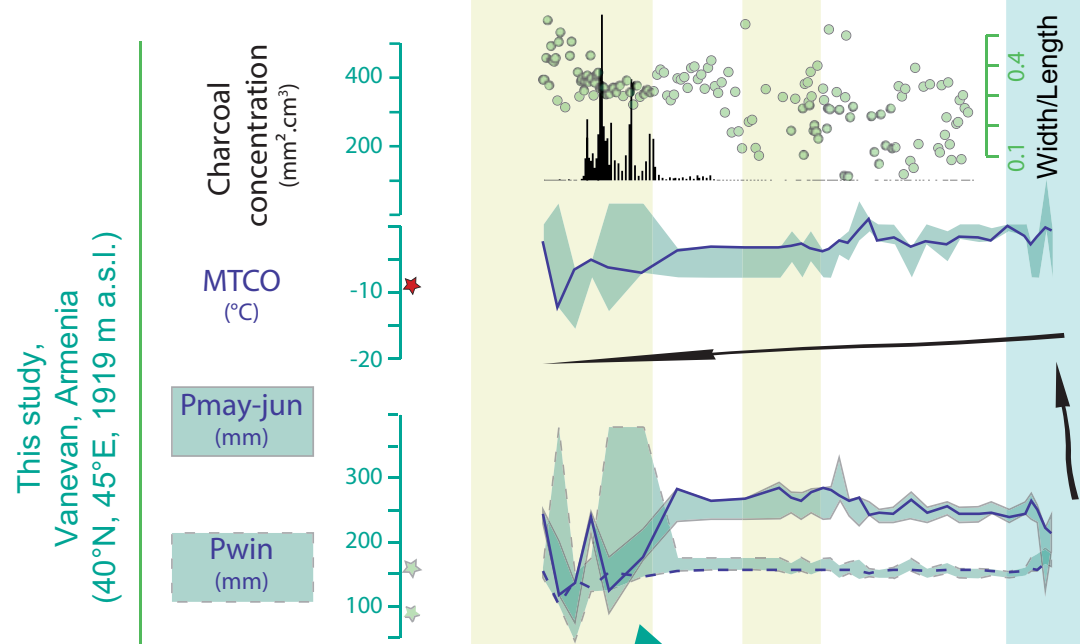

Hygrophilous herbs (\%)

Arboreal Pollen (\%)
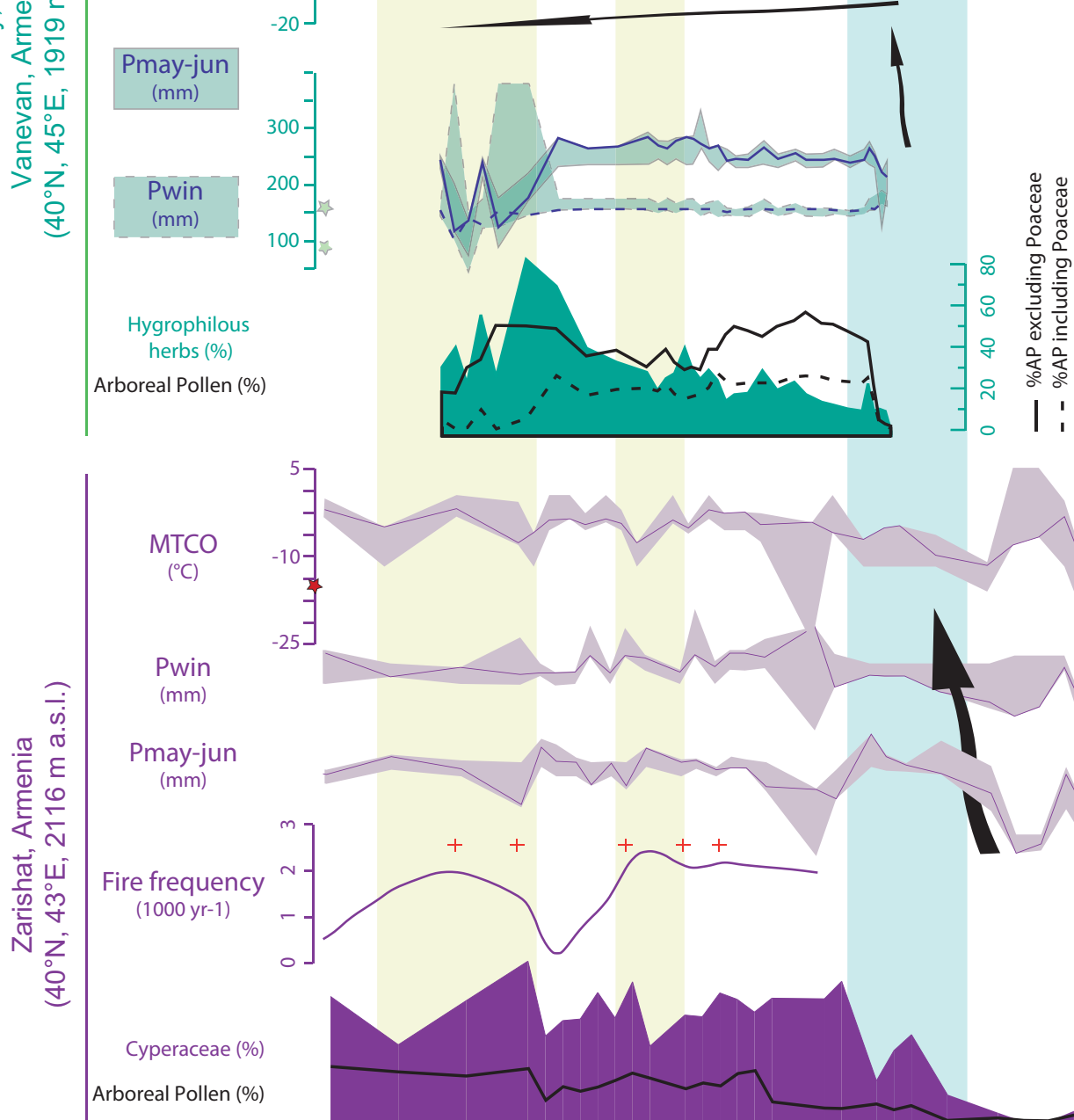

Paravani, Georgia

( $41^{\circ} \mathrm{N}, 43^{\circ} \mathrm{E}, 2073 \mathrm{~m}$ a.s.l.)

Arboreal pollen (\%)

22GC3, Black Sea

$\left(42^{\circ} \mathrm{N}, 36^{\circ} \mathrm{E}\right)$

Temperate deciduous

forest (scores)

Mirabad, Iran

$\left(33^{\circ} \mathrm{N}, 47^{\circ} \mathrm{E}, 800 \mathrm{~m}\right.$ a.s.l.)

rainfall regime

$\delta 180 \%$ PDB

\section{Zeribar, Iran}

A $\quad\left(35^{\circ} \mathrm{N}, 46^{\circ} \mathrm{E}, 1300 \mathrm{~m}\right.$ a.s.I. $)$ Arboreal Pollen (\%)
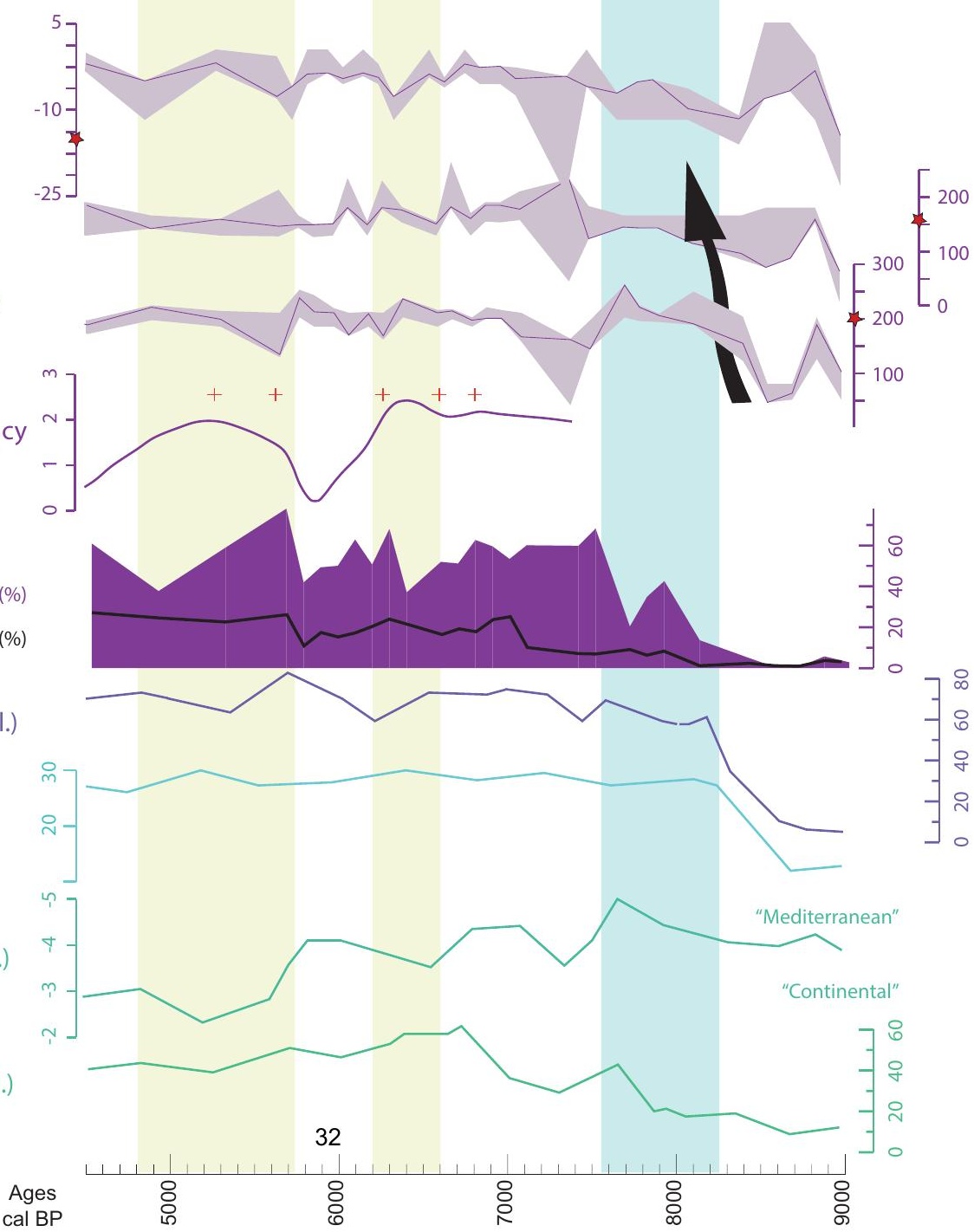